\title{
FDI and licensing strategies by Dutch multinationals in Japan
}

Citation for published version (APA):

Belderbos, R. A. (1998). FDI and licensing strategies by Dutch multinationals in Japan. NIBOR, Netherlands Institute of Business Organization and Strategy Research. NIBOR Research Memorandum No. 02 https://doi.org/10.26481/umanib.1998002

Document status and date:

Published: 01/01/1998

DOI:

10.26481/umanib.1998002

Document Version:

Publisher's PDF, also known as Version of record

\section{Please check the document version of this publication:}

- A submitted manuscript is the version of the article upon submission and before peer-review. There can be important differences between the submitted version and the official published version of record.

People interested in the research are advised to contact the author for the final version of the publication, or visit the DOI to the publisher's website.

- The final author version and the galley proof are versions of the publication after peer review.

- The final published version features the final layout of the paper including the volume, issue and page numbers.

Link to publication

\footnotetext{
General rights rights.

- You may freely distribute the URL identifying the publication in the public portal. please follow below link for the End User Agreement:

www.umlib.nl/taverne-license

Take down policy

If you believe that this document breaches copyright please contact us at:

repository@maastrichtuniversity.nl

providing details and we will investigate your claim.
}

Copyright and moral rights for the publications made accessible in the public portal are retained by the authors and/or other copyright owners and it is a condition of accessing publications that users recognise and abide by the legal requirements associated with these

- Users may download and print one copy of any publication from the public portal for the purpose of private study or research.

- You may not further distribute the material or use it for any profit-making activity or commercial gain

If the publication is distributed under the terms of Article $25 \mathrm{fa}$ of the Dutch Copyright Act, indicated by the "Taverne" license above, 


\title{
FDI and Licensing Strategies by Dutch Multinationals in Japan
}

\author{
René A. Belderbos* \\ NIBOR/RM/98/02 \\ Faculty of Economics and Business Administration \\ NIBOR (Netherlands Institute of Business Organization and Strategy Research) \\ Maastricht University \\ Department of Management Science \\ P.O. Box 616 \\ 6200 MD Maastricht \\ The Netherlands \\ Telephone: +31433883806 \\ Facsimile: +31433258495 \\ Email: r.belderbos@mw.unimaas.nl
}

\footnotetext{
* I would like to thank Rajneesh Narula for helpful comments and the Science Policy Research Unit of the
} University of Sussex for financial support. 


\title{
FDI and Licensing Strategies by Dutch Multinationals in Japan
}

\author{
Keywords: \\ business administration and economics (M) \\ international economics and trade $(\mathrm{F})$
}

JEL Code: F23

\begin{abstract}
After reviewing the stylised facts concerning Japan's low level of inward investment and the explanations for these facts put forward in the literature, this paper examines the licensing and investment behaviour of Dutch multinational enterprises in Japan. It is shown that aggregate data on Dutch foreign direct investment in Japan substantially underestimate the presence of Dutch firms. Survey data indicate that employment in affiliates of Dutch multinationals reached at least 12,000 in 1995. The largest five industrial groups (Shell, Unilever, Philips, Akzo-Nobel and DSM) are responsible for more than 90 percent of Dutch investment. Dutch affiliates on balance register a trade surplus with the rest of the world and with the Netherlands, which contrasts with the trade pattern of other foreign affiliates in Japan. The trade surplus is due to the active procurement of Japanese components and materials for world-wide operations by some affiliates, and the export-oriented manufacturing operations of affiliates in the electronics and speciality chemicals sectors. The data also reveal a diversity of investment strategies, from a focus on wholly and majority owned operations and intra-group transfers (Shell and Unilever), to an almost exclusive use of joint ventures coupled with licensing agreements with independent Japanese firm (DSM and Akzo-Nobel). A striking feature of Dutch investment in Japan remains the complete absence of a large number of multinationals with expanding operations in Europe and the United States. The new opportunities for market entry and acquisitions in Japan in the late 1990s, demonstrated by the expansion of a number of Dutch firms, warrant a much greater focus on the Japanese market than has been the case until today.
\end{abstract}




\section{Introduction}

It is commonly understood that Japan is the outlier among the major industrialised countries in terms of its foreign direct investment (FDI) position. Japanese statistics based on notifications of foreign investments to Japan's Ministry of Finance show a cumulative balance of outward over inward investment of 14 to 1 in 1995 [MOF (1995)]. This imbalance is due to a low level of inward investment, which has incited much debate about the trade and investment barriers facing foreign firms in Japan and its historical restrictions on inward investment until the late 1970s. This paper examines the investment position of Dutch multinationals in Japanese industries. It does so by examining in turn aggregate FDI data, survey data among foreign affiliated firms in Japan by industry, and characteristics of the main subsidiaries of Dutch MNEs in Japan. Comparisons are made with FDI from other countries to highlight strengths and weaknesses of Dutch firms. Since it has been argued that trade and investment barriers have forced foreign firms to rely extensively on licensing to exploit their technological and marketing strengths in Japan, the available information on the number of licenses sold by Dutch firms in Japan is examined as well.

The pattern of Dutch firms' involvement in Japan cannot be fully understood without due attention to the particularities of the trade and investment environment in Japan. The next section first establishes the 'stylised facts' concerning inward FDI in Japan (2.1). The empirical literature on FDI in Japan is reviewed to seek explanations (2.2), and attention is given to the most recent trends of deregulation and decreased hostility to foreign acquisitions providing greater opportunities for foreign firms (2.3). Section 3 examines Dutch firms' involvement in Japan by looking at investments flows and stocks (3.1), characteristics of Dutch MNEs' operations in Japan by industry (3.2), and licensing patterns by industry. Section 4 then takes a micro focus in presenting key data on the main subsidiaries of Dutch MNEs in Japan in 1995 (4.1). Information on licensing behaviour by Dutch MNEs in Japan, though only available for the period 1981-1986, highlights differences in investment behaviour between firms. Section 5 concludes.

\section{Japan's Low Level of Inward Investment}

An often quoted publication by Japan's Ministry of International Trade and Industry (MITI) suggests that foreign affiliated firms are responsible for a mere 0.9 percent of total sales of incorporated businesses in Japan [MITI (1995a)], which compares to a figure exceeding 10 percent in the United States [Weinstein (1996a)]. However, these aggregate 
figures have to be qualified considerably after more careful examination of the data, while they also hide substantial variation across industries. This section seeks to establish the 'stylised facts' pertaining to inward FDI in Japan (paragraph 2.1) before turning to the explanations given for the characteristics of this inward investment (paragraph 2.2). Paragraph 2.3 looks at some recent trends in foreign firms' involvement in Japan.

\subsection{FDI in Japan: Stylised Facts}

\section{The Investment Imbalance}

How does Japan's FDI imbalance compare with the FDI positions of other industrialised countries? The figures on investment notifications from the Ministry of Finance suggest a major investment imbalance but are unlikely to give an accurate picture: the figures include planned investments which are not necessarily followed through, and divestments and loan repayments are not recorded (but neither are reinvested earnings or expansions of branches). As an alternative and comparable indicator of the FDI imbalance, Table 1 shows outward and inward FDI based on balance of payments data during the period 1990-1994. The figures appear to confirm Japan's huge FDI imbalance: with cumulative FDI outflows of 127 billion US\$ and inflows of 6.8 billion US\$, Japan recorded a outward to inward FDI ratio of 18.6. This compares to ratios of 1.3 for the United States, 1.2 for the United Kingdom, 1.5 for France, and 1.8 for the Netherlands. On the other hand, Japan's imbalance is not entirely unique since Germany recorded a ratio of 15.4. Although the German ratio is affected by a large divestment in 1994, the exceptionally low Japanese inward investment figure for 1993 is also due to a large (1.65 billion US\$) divestment by the Dutch electronics group Philips from a joint venture with Matsushita Electric (see paragraph 4.1).

\section{INSERT TABLE 1}

The balance of payments data in Table 1 still have several drawbacks. They do not include reinvested earnings and do not take account of revaluation of assets. More fundamentally, FDI flow data only measure the share of foreign affiliated firms' assets which is financed from the investing firms' home country. They underestimate the importance of foreign firms' activities in the local economy since subsidiaries also rely on local as well as international loans and equity to finance their operations. ${ }^{1}$ Survey data on foreign affiliated firms do not have this

1 There is evidence that the parent firm is certainly not the main source of finance for affiliates in Japan. In the 1994 MITI survey among foreign affiliated firms in Japan, foreign subsidiaries reported that only 10 percent of all loans were obtained from the parent firm, while the parent financed only 1 percent of investments in fixed capital [MITI (1995a, 161-163)]. 
drawback. ${ }^{2}$ Table 2 presents figures on Japan's investment imbalance, world-wide as well as with Europe and the United States separately, desaggregated by industry. The data are employment figures drawn from MITI's surveys among foreign affiliated firms in Japan [MITI (1995a)] and Japanese multinational enterprises [MITI (1995b)]. There are a number of possible biases in these figures. The surveys are not mandatory and response rates are not very high (65 percent for outward FDI and 50 percent for inward FDI) and may vary across industries. The ownership criteria for outward and inward FDI are unfortunately not comparable. Outward FDI excludes firms in which the Japanese investors have a less than 10 percent stake but a minimum of 33 percent is required in case of inward FDI. As a solution to this problem, and considering that outward FDI has the greater response rate, the figures on Japanese affiliates abroad are restricted to majority owned subsidiaries, for which MITI (1995b) does publish a number of separate tables.

\section{INSERT TABLE 2}

In Table 2, the ratio of outward to inward investment based on employment in multinational enterprises is estimated at about 8 to $1 .^{3}$ This is still high, but considerably below MOF's ratio of 14 and the ratio in Table 1. The bilateral investment imbalances with the United States (3.6) and Europe (4.9) are again considerably smaller. ${ }^{4}$ There are also major differences across industries. Much lower world-wide investment imbalances are recorded for oil, chemicals \& pharmaceuticals, wood \& paper, and non-ferrous metals ${ }^{5}$, - all industries in which Japanese firms do not possess clear ownership-specific advantages vis-à-vis foreign firms. In oil, chemicals \& pharmaceuticals (US), and precision machinery (US and Europe), the figures show a FDI deficit. In contrast, the highest investment imbalances are recorded for industries in which Japanese firms are major competitors on world markets: transport machinery (automobiles, motor cycles, shipbuilding) and steel. In the electronics industry, employment in Japanese-affiliated subsidiaries abroad (mostly in consumer electronics and components) is very substantial, but the investment imbalance is held in check by US investments by IBM and Apple in the computers industry. The investment in balance in

\footnotetext{
2 Furthermore, notification data on inward FDI by MOF (1995) are not desaggregated by industry and country but such desaggregation is available for outward FDI.

${ }^{3}$ If minority owned overseas subsidiaries of Japanese firms were to be included, the ratio would increase to 11.5.

${ }^{4}$ The investment ratio with the US compares quite well with figures drawn from US Department of Commerce data on Japanese affiliates in the US and US affiliates in Japan. Dunning and Narula (1994) report that US FDI in Japan in 1990 was 21 billion US\$, while Japanese FDI in the US was 83 billion US\$, which implies a FDI ratio of roughly 4.

${ }^{5}$ Canadian investment is responsible for foreign affiliated employment in non-ferrous metals. Alcan aluminium, the world's second largest aluminium producer, has controlling stakes in two listed Japanese aluminium manufacturers, Toyo Aluminium and Nippon Light Metal Industries.
} 
textiles is a result of large investments in Asian manufacturing plants which mostly export back to Japan.

The non-manufacturing sectors distribution, services (transport, consultancy, software, advertising, leisure) and 'other non-manufacturing' industries (mining, construction, telecommunications, banking \& insurance, real estate, utilities) have higher than average investment imbalances. Given that Japanese firms are not perceived to possess advantages in most non-manufacturing sectors (clear examples are insurance, telecommunications, and software), these sectors appear the most important outliers. Non-manufacturing sectors are much more tightly regulated than the manufacturing sector in Japan, while the remaining explicit restrictions on foreign ownership are concentrated here as well, as will be seen below.

\section{Foreign Firms' Presence in Japan}

Based on its survey among foreign-affiliated firms in Japan, MITI (1995a) reports that they are responsible for a mere 0.9 percent of sales of incorporated businesses in Japan; for the manufacturing sector this is 2.3 percent. These figures also appear in MITI's English language publications [JETRO (1996)] and have been quoted to emphasise the meagre role of foreign firms in the Japanese economy. However, it is obvious that the MITI figures substantially underestimate the stake of foreign firms: there is no correction for the 50 percent response rate, the survey does not include the whole population of foreign affiliated firms, and affiliates owned less than 33 percent are excluded (and therewith large investments such as Ford's in Mazda). Weinstein (1996a) uses the more comprehensive survey data published by Toyo Keizai (1995) and estimates the sales share of foreign firms as closer to 6 percent, six times higher than the MITI number. Foreign firms' presence in Japan is still lower than in other industrialised countries, but not as dramatically as suggested by official figures published by MITI.

\section{Entry Modes}

Inward investment in Japan has a particular distribution among the three main modes of entry (wholly owned subsidiaries, joint ventures, and acquisitions). There is an abundance of joint ventures but wholly owned subsidiaries, and acquisitions in particular, are underrepresented. The 1994 MITI survey indicates that 52 percent of foreign affiliated firms responding to the survey were wholly owned, while 36 percent were minority joint ventures. A similar survey in 1991 shows that in only 7.1 percent of cases did foreign firms gain control 
by acquiring a stake in an existing Japanese firm. ${ }^{6}$ Encarnation (1993) shows that US multinationals have entered Japan much more often by way of minority owned joint venture than they did in other industrialised countries: minority owned ventures were responsible for 63 percent of all US affiliate sales in Japan, but for only 23 percent of sales in all developed countries. Figures on mergers and acquisitions involving Japanese firms also show a large discrepancy between the number of foreign acquisitions in Japan (18 in 1990), and both the number of Japanese acquisitions abroad (440) and Japanese acquisitions in Japan (293) [Lawrence (1992)].

\section{Licensing}

Another feature of foreign firms' involvement in Japan, and the corollary of their limited direct investment in Japan, is a relatively strong reliance on licensing as a means to exploit know-how and technological advantages. Balance of payments data for 1994 show that Japan is by far the greatest importer of technology as measured by payments of royalties and licensing fees. Japan paid fees amounting to 8.29 billion US\$, higher than payments by the US (5.67 billion), Germany (4.44 billion), and the UK (2.40) [JETRO (1997)]. The available data on US multinationals' investment and licensing in Japan suggest that a substantial share of royalty and licensing income is from firms in which they do not have an equity stake rather than from affiliated firms. The ratio of US multinationals' royalty and licensing income from affiliated firms to payments by unaffiliated firms in Japan was 1.37 in 1990, which contrasted with a ratio of 3.63 for the rest of the world [Dunning and Narula (1994), Lawrence (1992)].

\subsection{Explanations}

A great number of explanations for the particular characteristics and low level of inward FDI in Japan have been brought forward. This paragraph briefly reviews the main arguments.

\section{Regulation of Inward Investment}

The most obvious and important factor explaining Japan's low level of inward investment is the legacy of three decades of tight restrictions on and regulation of inward investment. In

\footnotetext{
${ }^{6}$ See MITI (1992). The more recent MITI surveys no longer ask for the establishment details of the subsidiaries. Note that the 1991 survey only covered subsidiaries in which foreign firms had a stake equal to or greater than 50 percent.
} 
the post war period of rebuilding the economy, the Japanese government saw the regulation of the transfer of technology (licensing) and capital (direct investment) to Japan as an indispensable part of its industrial policy which aimed at fostering indigenous capabilities. After regaining independence in 1949, Japan passed two laws, the Foreign Exchange and Foreign Trade Control Law and the Foreign Investment Law, which gave MITI broad powers in regulating both inward investment and licensing by foreign firms in Japan. MITI used these powers to ban acquisitions and most wholly owned foreign ventures, and to negotiate instead cost effective licensing deals for Japanese companies [Bailey, Harte and Sugden (1992), Odagiri and Goto (1996, 44-51)]. For instance, IBM was allowed to set up a wholly owned subsidiary but only after it licensed major computer patents to Japanese competitors. Texas Instruments was forced to engage in similar licensing deals while it was refused permission to set up a wholly owned subsidiary (instead it was agreed that it set up a joint venture with Sony). In 1967, Japan reluctantly introduced the first step-wise liberalisation of foreign investment, which had become necessary after Japan joined the OECD in 1963. The 1967 refinement to the practice of administering the Foreign Investment Law implied that for selected industries, 100 percent ownership was allowed in principle, while in a group of other industries minority ventures were allowed if a number of conditions were met. MITI retained broad powers to disapprove foreign investments in the industries falling under the new regime [Bailey, Harte and Sugden (1992)]. Under successive changes in implementation of the law over the next 13 years, more industries were added to the minority owned and then the wholly owned categories. Yet a number of industries in which foreign firms had considerable strengths and wished to invest, such as semiconductors, computers, pharmaceuticals, and distribution, were not among them [Nakamura et al. (1995)]. It was not until 1980, with the abolition of the Foreign Investment Law, that foreign investment became liberalised with the exception of only a limited number of industries. ${ }^{7}$ Since the 1980 s, prior notification to the Bank of Japan is all that is required to allow investment projects, including acquisitions, although MITI retained the (sparsely used) right to block investments. ${ }^{8}$ In 1992, the notification requirement was finally changed to ex-post notification.

Government regulation of inward investment explains a good deal of the low level of inward investment and the relative importance of licensing, as well as the importance of joint ventures and the scarcity of acquisitions. MITI's strategy of fostering capabilities in Japanese firms deprived foreign firms of investment opportunities exactly at the time when their relative competitive advantage made (wholly owned) investments the preferred way of exploiting these

\footnotetext{
7 Agriculture, oil refining, leather, forestry and fisheries, aviation, and investment trusts are exempted from liberalisation, while other restrictions on foreign investment apply in space development, defence and aircraft industries, utilities, telecommunications, and broadcasting [Nakamura et al. (1995)].

${ }^{8}$ For instance, in 1984, MITI protected a number of Japanese firms, including electronics group Hitachi and oil firms Arab Oil and Tonen, by prohibiting foreign firms to acquire a stake [Nakamura et al. (1995)].
} 
advantages in Japan. Restrictions were greatest in those industries where foreign firms were dominant and the lifting of restrictions usually took place after Japanese firms had been able to attain competitiveness themselves. However, although the selectivity and duration of this policy intervention coupled with increased Japanese competitiveness may explain to an extent why there was no big surge in inward investment after 1980, other factors must be responsible for the 'stylised facts' of inward FDI observed in the early 1990s.

\section{Non-Tariff Barriers and Restrictive Business Practices}

A variety of government regulations and business practices as well as economic factors have been put forward as having an influence on the presence of foreign firms in Japan in general and inward FDI in particular. Following Sanna-Randaccio (1996), these can be distinguished into factors affecting trade (exports), those affecting foreign firms' sales in the local market in general (both exports and sales of locally produced goods), and factors affecting inward investment only. Barriers solely affecting imports to Japan have generally been very low throughout the 1980s and 1990s: tariff levels are the lowest among industrialised countries and quota are mainly concentrated in agricultural products. This implies that there are not many incentives for foreign firms to engage in 'tariff jumping' FDI.

In contrast, non-tariff and private barriers to foreign firms' sales are perceived to be of considerable importance. A number of these affect foreign firms and Japanese entrants alike. They include idiosyncratic technical and product standards, and health, safety, and sanitary regulations, inadequate access to government contracts and procurement schemes by semigovernment institutions, lack of transparency in government regulations (administrative guidance), inadequate access to business and industry associations, and difficulties in winning corporate clients having long standing ties with other Japanese firms in particular within keiretsu (industrial groups). ${ }^{9}$ An important factor is also Japan's multi-layered distribution system. Japan's electronics, automobile, and pharmaceutical firms established large distribution networks in Japan in the 1960s. Import barriers and restrictions on inward investments allowed them to maintain profit margins and to finance the considerable cost of these investments. ${ }^{10}$ Although the number of independent retailers and wholesalers has risen in the last decade, Japanese manufacturers still control the majority of retail outlets. Restrictions on entry in the distribution sector through the Large Scale Retail Store Law (and on foreign entry through the Foreign Investment Law) have long prohibited large retailers and wholesalers to compete effectively with incumbent retailers and wholesalers linked to

\footnotetext{
${ }^{9}$ See also Mason (1995) and Graham and Yoshitomi (1997).

${ }^{10}$ See Belderbos and Holmes (1995) for a discussion of the Japanese CTV industry.
} 
manufacturers. Given the relative scarcity of independent distributors which are more likely to stock imported goods and goods manufactured by foreign entrants, foreign firms wishing to reach a large share of the Japanese market either had to invest substantial amounts over a long period in setting up their own distribution networks, or to negotiate access to distribution channels of established Japanese manufacturers. Only the larger foreign firms with sufficient financial resources and marketing potential effectively had the option to choose the first route. ${ }^{11}$ The distribution system appears the more important barrier considering that it is precisely in this sector where Japanese manufacturers have expanded operations in the United States and Europe. Williamson (1993) argues that control over distribution, which takes care of after sales services and facilitates feedback on consumer tastes and better marketing, explains a substantial part of Japanese firms' export successes. ${ }^{12}$ In conclusion, the distribution system and other non-tariff barriers have had a negative impact on both imports and inward investments. Such barriers have altered the trade-off between internalisation (exports or FDI) and licensing in favour of the latter. Where investment occurred, foreign firms had strong incentives to link up with a Japanese partner in a joint venture, since Japanese incumbents had knowledge of idiosyncratic local standards and practices, and access to distribution outlets, corporate clients, and government bodies. ${ }^{13}$

A third group of factors works to limit the locational advantages of manufacturing FDI in Japan. ${ }^{14}$ The 1980s were characterised by rising costs of labour, land, and real estate. The latter reached astronomical levels at the height of the 'bubble economy' in 1989. There were also increasing shortages of skilled labour which made it difficult to recruit personnel. Weinstein (1996b) argues that the life time employment system operated by the larger Japanese firms and the strong emphasis on in-company training put foreign firms (in particular new entrants and smaller firms) at a structural disadvantage in Japan. The limited mid-career labour market hampers the recruitment of experienced personnel and managers, the type of employee which is in high demand by firms starting up their business in Japan. Moreover, foreign firms find it difficult to build up a similar reputation among graduates as established Japanese firms in terms of offering long term job security and career and training

\footnotetext{
${ }^{11}$ See Batzer and Laumer (1989) for an examination of distribution channels for foreign firms in Japan.

12 Yamawaki (1991) and Belderbos and Sleuwaegen (forthcoming) found evidence that Japanese firms' investments in distribution networks in the US and the EU have stimulated exports. Encarnation (1993) does note that US multinationals have to some extent responded to the specific conditions in the Japanese market: they have invested relatively more in the distribution sector in Japan than they have done in other developed countries.

13 Barkema et al. (1996) argue that such joint ventures are also more likely to be short-lived, because of the greater difficulties facing such ventures in the light of cultural and managerial differences, but also because accumulation of local experience by the foreign firm undermines the basis of the joint venture. They find that (joint) ventures of Dutch multinationals in Japan in particular have a shorter life than subsidiaries elsewhere (with the exception of Africa).

14 To the extent that these factors also limit the attractiveness of FDI in distribution, they again favour licensing over internalisation following the arguments above.
} 
opportunities. A comparison of foreign and Japanese firms' hiring practices shows that foreign firms have to paying higher starting salaries in order to attract Japanese graduates [Weinstein (1996b, pp 162-168)].

The various disadvantages of locating in Japan are not offset by incentives schemes for (foreign) investors that have become so prevalent in the EU and in most US States. Although the Japanese government has changed its stance from restricting to welcoming foreign investors and has established support agencies for foreign investment, financial incentives are very limited. There are no important grants nor substantial tax incentives available. The Japan Development Bank and local government bodies do offer low interest loans to investors under certain conditions, but in practice, investors still require collateral to put together a financial package. Only 26 out of 44 surveyed prefectural governments operated investment promoting policies by 1995 , of which not more than two had special programs to attract foreign investors. The relative lack of initiatives here is related to the centralised control over finance and taxation by the central government in Tokyo, which implies that prefectures cannot differentiate their policies to a large extent [JETRO (1996)].

A fourth group of business practices and regulations raise barriers to the acquisition of Japanese firms by foreign companies. These barriers are important because, as Lawrence (1992) points out, precisely because of the idiosyncratic characteristics of the Japanese market, foreign firms will have a strong preference for acquisitions to gain access to distribution channels and marketing knowledge. The scarcity of acquisitions must imply that barriers have reduced the overall level of foreign investment. There is some evidence pointing in this direction. In industries where foreign firms' presence is greatest, such as oil refinery and pharmaceuticals, ${ }^{15}$ MITI survey data for 1991 also show relatively high shares of entry through acquisitions [MITI $(1992,21)]$. It is often argued that cross-shareholdings within horizontal keiretsu constitute a major restriction for foreign firms to acquire Japanese companies [e.g. Lawrence (1992)]. However, the evidence does not appear conclusive. Although cross-shareholdings in horizontal keiretsu are important, the combined holdings of group firms in most cases does not reach a majority stake. Low levels of trading in shares of publicly quoted companies are also the result of the presence of other 'stable' shareholders such as not group-related insurance companies and (trust) banks. Insurance companies appear to provide 'stable shareholding' service to companies in exchange for their clientele. Tight government regulation of insurance premiums has ruled out direct competition in insurance markets and insurance companies have therefore looked for other ways to compete for

15 Nakamura et al (1995) estimate foreign-affiliated firms' share of sales in various industries, weighted by the foreign investment stake of foreign firms. The highest shares are reported for oil (16.4) and pharmaceuticals (13.4). 
customers [Weinstein (1996b)]. Government policies have in the past also fostered stable shareholdings in a more direct way. For instance, in the 1960s, the Ministry of Finance intervened in a depressed Tokyo stock market by buying up large quantities of shares. It later sold them on favourable terms to 'stable' shareholders such banks, insurance companies, and related firms [Odagiri and Goto $(1996,94)]$. Although the intervention also coincided with the liberalisation of foreign acquisitions and an apparent fear of potential foreign takeovers, 'stability' here in first instance meant that the shareholders would not sell the shares in the short term. Various tax incentives and regulations of the banking and insurance sector continue to provide substantial incentives for these stable shareholdings [Weinstein (1996a)]. ${ }^{16}$ Still, the shareholding pattern in itself is not a sufficient explanation. Firms must also be hostile to takeovers. Odagiri $(1992,330)$ argues that cross shareholdings also reflect a more fundamental feature of Japanese industrial organisation and corporate governance. Stable shareholdings allow managers to pursue the long term growth of the firm and is linked to life time employment systems and loyalty of workers to the firm. An acquisition by another firm is seen as a defeat not a rescue, and mergers and acquisition only tend to occur when firms are in serious difficulties. Firm-specific business culture and life time employment tend to make it hard for the acquirer to manage and integrate the acquired firm with its other operations and to benefit substantially from the acquisition. This is all the more so when the acquirer is a foreign firm with a very different corporate culture.

\section{Empirical Studies of Inward Investment in Japan}

A number of empirical studies of manufacturing FDI in Japan have incorporated some of the above factors in order to find explanations for the pattern of FDI. Eaton and Tamura (1994) estimate a gravitation model of trade and FDI for the US and Japan and indeed conclude that the low level of US FDI to Japan is an outlier which cannot be explained by their empirical model. They posit that the specific characteristics of the Japanese market have favoured licensing agreements. A recent study by the Japan Development Bank (1997) establishes that Japan is an outlier in a regression analysis of FDI flows to Japan and other OECD countries. The study finds that the high corporate tax burden, overvaluation of the Yen, and the difficulties in hiring personnel due to low labour mobility can explain part of Japan's deviation from FDI patterns in other OECD countries. Lawrence (1992) attempts to measure the effect of keiretsu presence on inward investment. In a cross industry analysis with

\footnotetext{
16 Tax advantages also explain part of the phenomenon of shareholdings in vertical keiretsu: suppliers and distributors centred around major manufacturing firms. Here group firms and in particular the core firm usually hold a majority stake in suppliers and distributors. By keeping subsidiary units small, firms can benefit from a favourable tax regime applicable to companies which can be classified as small and medium sized enterprises [Weinstein (1996a)].
} 
10 observations he finds that the share of both horizontal and vertical keiretsu firms in industry sales has a significantly negative effect on the market share of foreign-affiliated firms. However, these results are highly contentious given the small number of observations and the fact that the controlling variables in the model (R\&D intensity and concentration) which should measure conventional barriers to entry and FDI, have a counter-intuitive positive sign [cf. Kogut and Chang (1991), Kim and Lynn (1987)]. Weinstein (1996b) in a similar analysis combining cross industry and time series analysis also finds a negative sign of keiretsu presence on inward FDI. However, the coefficient was in most cases not significant, while the size of the effect of keiretsu was small relative to the positive secular time trend in FDI inflows. Wakasugi (1995) finds a significant correlation between the sales share of foreign firms in Japanese industries and the ratio of royalty and licensing fees inflows over outflows. He also uses data from the MITI surveys among foreign-affiliated firms to establish that the level of foreign penetration is positively related to the level of foreign subsidiaries' royalty payments to the parent and the reliance on imports of intermediates from the parent. The results suggest that ownership-specific factors are an important determinant of FDI patterns. In other words, industry-specific barriers are not such that they distort FDI decisions to the extent that the cross-industry pattern of FDI does not reflect the relative competitive advantage of foreign firms. On the other hand, the results are also consistent with the persistence of important generic barriers to foreign penetration which affect most industries. One would expect a particularly strong correlation between ownership-specific factors and FDI in Japan because the presence of such barriers will allow only the firms with very robust competitive advantages to make headway in the Japanese market.

Nakamura et al. (1995) offer the most comprehensive analysis of inward FDI in Japan. They draw on a new mandatory MITI census among all incorporated firms in Japan to enable analysis of foreign firms' sales shares in 38 industries. There results do not support the hypothesis that the presence of horizontal and vertical keiretsu impedes FDI. In contrast, conventional entry barriers, proxied by the Herfindahl concentration index, and capital and $\mathrm{R} \& \mathrm{D}$ intensity are found to exert a significantly negative influence. The results concerning conventional entry barriers contrast to an extent with those found for Japanese FDI in the US in Kogut and Chang (1991). The latter study found that US R\&D intensive industries attract more Japanese FDI, particularly in the form of acquisitions. The negative effect of R\&D intensity on inward FDI in Japan is consistent with the existence of barriers to this type of acquisitions in Japan. The analysis also included two dummy variables for historic and present government restrictions on FDI which had a counter-intuitive positive sign. The positive sign for present restrictions appears solely driven by the oil industry, where foreign penetration is high due to a historic dominance of US and European firms, despite a system of formal approval for inward FDI. In oil refining, four of the top 7 Japanese firms are controlled 
by foreign interests. The dominance of foreign firms is a direct result of Japan's post-war need to secure a stable energy supply. Only the large European and US oil companies had substantial exploration interest and access to oil supplies, which gave them substantial bargaining power in negotiations with the Japanese government. In general it can be argued that the fact that MITI restricted those industries in which Japanese firms were lagging behind foreign competitors introduced a positive correlation between such restrictions and foreign firms' competitive advantages and hence FDI.

In conclusion, the empirical work indicates on balance that investment barriers are at present much less industry-specific (at least for manufacturing industries) but are general features of Japanese regulatory and business practices. Conventional entry barriers are important as well, while barriers to acquisitions appear to be a major impediment to foreign penetration.

\subsection{Recent Trends}

Recent trends in the 1990s indicate that many of the distinctive features of inward FDI are finally changing. The main driving force has been Japan's most prolonged post-war recession which followed the burst of the 'bubble economy' in late 1989. Many firms faced severe problems with the appreciation of the Yen and the slump in the domestic market in the first half of the 1990s. After several years of severe losses, Mazda Motor in 1996 allowed Ford to increase its stake to a de facto controlling share of 33.8 percent for 52.9 billion Yen. Ford sent a managing director to lead the firms' reorganisation and integration with Ford's international operations. This was the first time in post-war history that a foreign firm acquired a controlling stake in one of Japan's prominent industrial firms. Earlier, South Korea's Samsung had acquired controlling stakes in microscope and optical equipment manufacturer Union Optical (listed at the Tokyo Stock Exchange) in 1995, and in the specialised audio manufacturer Lux (traded at the over the counter market) in $1994 .{ }^{17}$ Given the historic rivalry between Korean and Japan, these acquisitions by a South Korean firm were unprecedented and would have been unthinkable in the 1980s. Three more listed electronics firms were acquired by foreign companies. Kodak acquired a controlling stake in Chinon Industries in 1997, a mid-sized optical equipment maker. Audio manufacturer Sansui was acquired by Polly Peck of the UK and later sold to the Canadian/Hong Kong consumer products group Semi Tech. Semi Tech later acquired a second listed audio producer, Akai. Akai (Mitsubishi Electric and Mitsubishi Group), Mazda (Sumitomo Group), and Lux (Alps and Mitsui Group) were or still are members of vertical or horizontal keiretsu and not the

${ }^{17}$ Nikkei Weekly, 23 January 1995. Samsung paid 52 million US\$ for its stake in Union Optical. 
independent firms which are seen as the typical target of foreign acquisitions. Recent figures on mergers and acquisitions in Japan confirm a rapid rise in foreign takeovers, with the value of foreign acquisitions continuously breaking records. The record in 1994 of 1.83 billion US\$, was surpassed by 2.6 billion US\$ worth of transactions in 1995 and 3.04 billion US\$ (43 cases) in $1996 . .^{18}$

Scattered evidence also indicates a trend towards a greater share of majority or wholly owned ventures in inward FDI. This trend was already apparent in the early 1990s as observed by Lawrence (1992). In the 1990s, a number of foreign automobile, chemical and pharmaceutical firms acquired a majority stake in their joint ventures with Japanese firms, or set up separate wholly owned ventures in Japan for the first time. An example is pharmaceutical firm Glaxo (UK) which bought out its joint venture partner in Nippon Glaxo for 66 billion Yen in 1996. The Dutch electronics group Philips has also been active in establishing full ownership of a number of Japanese ventures (see paragraph 4.1).

The above suggests that the level of FDI in Japan should be increasing as well. Dunning and Narula (1994) note that already in the late 1980s US multinationals were moving towards internalisation of ownership advantages through FDI and away from reliance on licensing to independent Japanese firms. ${ }^{19}$ MOF's FDI notification statistics show a relatively stable value of new FDI inflows of between 3-4 billion US\$ in the first half of the 1990s. A major change in FDI trends finally occurred in 1996, in which year FDI surged to almost 7 billion dollars, the highest level ever. In contrast FDI flows based on balance of payments data have not shown a similar increase (see Table 1). The latter net FDI figures are reduced by a number of large divestments and rationalisations of older joint ventures by foreign firms in Japan. MOF notification data are gross figures which do not include withdrawals.

FDI has been spurred by the new opportunities for acquisitions and the fall in the costs of stocks, land and real estate in the mid 1990s. The depreciation of the Yen in 1996 appears to have given foreign firms the signal to implement their investments plans. The Japanese government has also slowly but steadily brought standards and regulations in line with international practices and has made some progress in increasing the transparency of regulations and public procurement schemes. The government's deregulation initiatives in a number of areas such as banking and insurance, retailing, energy, and telecommunications have provided greater marketing opportunities for foreign firms. A good example is the partial repeal of the Large Scale Retail Store Law in 1989 which has led to an increasing role of

\footnotetext{
18 See Financial Times, 23 January 1997.

19 The ratio of royalty receipts from affiliated firms to royalty receipts from independent companies rose to 1.37 in 1990 from 0.61 in 1982 [Dunning and Narula $(1994,48)$ ].
} 
large stores and foreign retailers. US toy retailer Toys R Us, whose pressure had been instrumental in the relaxation of the law, has increased the number of Japanese outlets to 51 in 1996 after setting up its first store in 1991. It is now Japan's largest toy seller with 75 billion Yen ( $\$ 610$ billion) in sales. ${ }^{20}$ Another illustrative example is the announcement by US firm Enron, world leader in natural gas development, to set up a range of industrial waste powered electricity plants in Japan following liberalisation of Japan's electricity wholesale market in $1996 .{ }^{21}$

In next two sections it will be seen how Dutch multinationals have adapted their Japanese operations to the specific conditions affecting inward investment and if they have been able to benefit from more favourable circumstances for foreign firms in recent years.

\section{Characteristics of Dutch FDI and Licensing in Japan by Industry}

The persistent barriers to inward investment in Japan are likely to concentrate FDI more in the larger and most competitive firms, since only these have the necessary financial resources and technological and managerial capabilities to overcome such barriers. Given that the greater share of Dutch FDI is by large MNEs with substantial world-wide operations, the 'big four' Shell, Philips, Unilever, and Akzo-Nobel, it would follow that the level and pattern of Dutch FDI is less affected by the specific conditions in Japan than FDI from other countries. Paragraph 3.1 examines FDI flow and stock data to establish both the weight of Japan in world-wide FDI by Dutch MNEs and the share of Dutch MNEs in total FDI in Japan. In paragraph 3.2 MITI survey data on foreign-affiliated firms in Japan are explored as an alternative measure of the inward investment position. The survey also sheds light on the trading behaviour and profitability of Dutch MNEs in Japan. Finally, paragraph 3.3 examines the available statistics on Dutch licensing in Japan.

\subsection{Dutch FDI in Japan: Investment Flows and Stocks}

Figures on FDI stocks published by the Netherlands Central Bank show that out of a total Dutch foreign investment stock of 259 billion guilders an almost meagre share of 0.5 percent

\footnotetext{
${ }^{20}$ Nikkei Weekly, 31 March 1997. The entry of Toys R Us has contributed to a strengthening of price competition in toy retailing. In 1993 more than half of the toys sold in Japan were priced below the manufacturers' suggested retail prices, up from 20 percent in 1988 [Japan Development Bank (1997, pp 8)].

${ }^{21}$ Nikkei Weekly, 17 March 1997.
} 
(1,293 million guilders) was invested in Japan in 1994 [DNB (1996)]. ${ }^{22}$ The share of Japan had been higher five years earlier in 1988, when a 1.1 percent share equalled 1,691 million guilders [DNB (1990)]. The main reason for this sharp decline in Dutch FDI stocks in Japan was the divestment by electronics group Philips from its joint venture with Matsushita Electric in 1993. This is illustrated by DNB statistics on Dutch FDI flows to Japan, which show a negative figure of 2796 million guilders in 1993. Whilst in 1988, 95 percent of FDI in Japan was concentrated in the electronics industry, by 1993 FDI in electronics was reduced to a few million guilders. Still, even the 1.1 percent figure for 1988 is puzzling. Although Shell has substantial operations in Japan (as will be seen in the next section), the stock data do not show any substantial investment in the oil \& chemical industries. It appears that FDI in Japan by Shell is mostly the responsibility of the UK arm of the group such that no FDI flows are recorded between the Netherlands and Japan. ${ }^{23}$

Another source of data on FDI in Japan, figures on notifications of investments to MOF, give an indication of the share of Dutch firms in total inward investment. MOF data show a substantially stronger Dutch investment position in Japan than DNB data. Dutch FDI reached a cumulative value of 2800 million US\$ over the period 1950-1994, which amounted to 8.2 percent of total inward investment [MOF (1995)]. Moreover, in the 1990s the Dutch share of new investments has generally been even higher, at around 10 percent. This may suggest that Dutch firms have been active investors in Japan in recent years, while large divestments (not included in the cumulative MOF data) have led to low levels of net FDI recorded in Dutch stock figures and balance of payments data. It should however be noted that MOF figures may exaggerate Dutch firms' FDI because the figures include investments by holding companies and financial subsidiaries established in the Netherlands primarily because of its advantageous tax regime for such activities. ${ }^{24}$

Trade data also provide a piece of evidence on the role of Dutch firms in Japanese markets. Here the picture is rather bleak. Only 1.1 percent of Dutch trade went to Japan in 1995, reason for the Dutch government to initiate an 'export to Japan' campaign with the establishment of a Japan Export Council (JAPTA) [MITI (1996)]. ${ }^{25}$ The Netherlands was responsible for a mere 0.6 percent of total Japanese imports, a share which should be

\footnotetext{
22 The distribution of the FDI stock in Japan over sectors was as follows: 1173 million in manufacturing and 120 million in trade and services. FDI stocks calculated by DNB incorporate reinvested earnings and are adjusted for revaluations.

${ }^{23}$ Perhaps this is so because of the historical presence in Japan of the UK arm Shell Transport \& Trading.

${ }^{24}$ Examples are SGS-Thomson and Pirelli. MOF does not correct for FDI by such financial subsidiaries, but DNB does [Van Nieuwkerk (1988)]. On the other hand, MOF figures also exlude FDI by Shell UK.

25 In contrast, more than 4 percent of Japanese trade goes to the Netherlands, which is partly due to the importance of the Netherlands as a base for European distribution activities.
} 
considered low for the sixth trading nation in the world. By industry, the Dutch import share reached a maximum of 1.6 percent for chemical products.

In summary, FDI statistics suggest a very limited presence of Dutch firms in Japan, but measurement and definition problems suggest that they hide more than they reveal. The next paragraph examines survey data on foreign MNEs in Japan as an alternative source of information.

\subsection{Characteristics of Dutch MNEs' Operations in Japan: Survey Data}

Survey data on foreign firms in Japan can give an indication of the importance of Dutch FDI across industries and show characteristics of the operations of Dutch affiliates. Table 3 presents MITI survey figures on the number of subsidiaries, the value of total assets, the number of employees and sales of Dutch affiliates in 1994. Given the 50 percent response ratio of the survey and the fact that response rates may differ across industries and countries, due caution should be exercised in interpreting the results. The share of Dutch firms in total inward investment in terms of number of employees and sales is about half the share based on the MOF data: 4 and 3.6 percent, respectively. The 63 Dutch affiliates responding to the survey had total assets of 288 billion Yen (roughly 2.5 billion US\$ at 1994 exchange rates). The affiliates employed 6724 personnel and had sales of 480 billion Yen. The largest number of employees is recorded in the electrical and electronics industry, which is to be attributed to the presence of Philips. Other manufacturing industries with relatively high employment figures are chemicals and pharmaceuticals, but here US and other European MNEs are large investors as well and Dutch firms are not responsible for an above average share of inward FDI. The high share of Dutch employment in the wood \& furniture industry is more likely to be a classification error. It is again clear from the figures that Shell does not report as a Dutch MNE. ${ }^{26}$ What does appear a robust finding is a higher than average share reported for the distribution sector (which includes general trading firms as well as trading arms of industrial firms) and a substantial share for 'other non-manufacturing' (including ING and ABN-AMRO in banking \& insurance and Nedlloyd in transport). ${ }^{27}$

\section{INSERT TABLE 3}

\footnotetext{
26 The operations of Unilever would appear not be included in the figures either.

27 In the rather unhelpful MITI classification, mining, construction, banking \& insurance, transport, real estate, telecommunications and utilities are grouped under 'other non-manufacturing', while leasing, software \& information services, advertising, consultancy, and the leisure sector are grouped under 'services'.
} 
The survey data also allow for a preliminary analysis of profitability and import and export behaviour. The available information is presented in Table 4. Overall, Dutch manufacturing affiliates are profitable: on average they reported a ratio of operating profits to sales of 2.8 percent in 1994. Most manufacturing industries, with the exception of general machinery and 'other manufacturing' reported profits, with chemicals, pharmaceuticals and electronics responsible for the highest earnings. This finding corresponds well with figures for the whole population of foreign-affiliated firms in Japan, which indicate that foreign firms on average earn higher profits than Japanese firms in the same industry [MITI (1995a)]. It may be that the difficulties in penetrating the Japanese market have led to a concentration of investments by the world's strongest multinationals, able to exploit their intangible assets profitably in Japan. It may also indicate, however, that there is a reluctance among foreign multinationals to make strategic investments in Japan and incur losses in initial years to build up a market presence in the long term. As for non-manufacturing industries, Dutch affiliates in the 'non-manufacturing' and 'service' sectors were also profitable, but distribution affiliates were on average loss making in 1994.28

\section{INSERT TABLE 4}

Table 4 also shows export intensities and import intensities (the ratio of imports to sales) and the contribution of Dutch MNEs to Japan's trade balance. Unfortunately, export and import data are no longer recorded separately for Dutch affiliates in the 1994 survey and had to be drawn from the 1991 survey instead. The 1991 survey only included affiliates in which foreign firms had a stake of 50 percent or more and it had a response rate of 52 percent. The export intensity figures show that not all manufacturing ventures are set up to serve the Japanese market: Dutch manufacturing affiliates on average exported 23.5 percent of turnover. This figure is mainly a result of the high export ratio for the electronics and precision machinery industries. In the former industry, Philips has a 50 percent stake in a publicly quoted audio and video manufacturer, Marantz, which exports a substantial share of it output to Europe and the United States. The export ratio in machinery industries reflects Japan's strength in these sectors. Dutch firms use their manufacturing presence not only to access the Japanese market, but also to learn from Japanese firms' strengths, to establish linkages with components suppliers and the local $R \& D$ infrastructure, and to develop products for export markets. Perhaps more surprising is the 24 percent export ratio reported by distribution affiliates. This appears to be due to the presence of distribution arms of manufacturing firms such as Philips Japan, which are also active in procurement of machinery

28 This appears not to be a persistent characteristic of FDI in this sector: the 1991 survey showed a profit ratio of 3.4 percent. For a number of other industries as well, 1991 figures were very different from 1994 figures: pharmaceuticals reported a loss in 1991 and general machinery a profit ratio of 18.4 percent [MITI $(1992,71)$ ]. 
and components for export to subsidiaries world-wide. It is more difficult to explain the high export ratio for the 'non-manufacturing' sector.

The import to sales ratio of Dutch affiliates reached 18 percent in 1991, 6 percent points lower than the export ratio. The only industries which relied strongly on imported goods and materials were chemicals and pharmaceuticals. Distribution affiliates reported a surprisingly low import to sales ratio of 20 percent. The result is that Dutch affiliates contributed to Japan's trade surplus in 1991. All affiliates together exported 58 billion Yen more than they imported. The electronics industry is the main contributor to this surplus (36 billion Yen), but the distribution sector also shows a substantial surplus (28 billion Yen). This trade behaviour of Dutch affiliates differs markedly from the trade behaviour of all responding foreignaffiliated firms. All foreign subsidiaries taken together reported substantially greater import than export figures in 1991 as well as in 1994, both in manufacturing and distribution. In 1994 the trade deficit by foreign affiliates was more than 2 trillion Yen (roughly 16 billion US\$). Dutch MNEs appear uncharacteristic in the sense that they have much less utilised investments in manufacturing and distribution to increase market access and to promote imports of intermediates and final goods into Japan. This finding, it should again be mentioned, would probably have been altered substantially had the affiliates of Shell been included in the figures.

The 1991 survey also contains figures on the direction of exports and the origin of imports. These give an indication of the effect of Dutch affiliates' trade behaviour on the bilateral trade balance between the Netherlands and Japan. The available information is presented in Table 5. No separate trade figures are available for the Netherlands, but the Netherlands is expected to be responsible for a large share of bilateral trade by the 'other Europe' group (European countries other than the UK, Germany, France, and Switzerland). For Dutch manufacturing affiliates, Europe was the most important destination of exports but the difference with Asia and North America was not that large. Since Europe was the primary source of imports the result is a trade deficit of the affiliates with Europe as a whole. However, this trade deficit only concerns trade with the group of four European countries, whilst the trade balance with other European countries including the Netherlands shows a surplus. Similar observations can be made for the trade behaviour of Dutch distribution affiliates: here a trade deficit with the four European countries is surpassed by a trade surplus with the rest of Europe. Hence, it is likely that manufacturing and distribution investment by Dutch firms in Japan have increased the Dutch trade deficit with Japan. ${ }^{29}$

29 This is only to an extent due to the 'gateway' function of the Netherlands. Although the fact that exports to 'other Europe' are relatively high is consistent with such an explanation, at the same time imports from 'other Europe' are low relative to imports from the large European countries. 


\section{INSERT TABLE 5}

\subsection{Dutch Licensing in Japan by Industry}

The distribution of licensing contracts across industries and the share of Dutch firms in foreign firms' licensing activity in Japan are indicators of the technological and marketing strengths of Dutch firms. Licensing contracts with Japanese firms are notified to the Bank of Japan if the value of the contract exceeds 3 million Yen. ${ }^{30}$ The Science and Technology Agency (STA) and its affiliated research institute, the National Institute for Science and Technology Policy (NISTEP) publish a yearly report with key statistics based on these notifications. The licensing contracts concern the transfer of rights for using know-how and patented technology, designs, trademarks, and technical guidance. Both contracts with independent Japanese firms and foreign-affiliated firms in Japan are included. The statistics can potentially be used to show the extent to which foreign firms exploit intangible assets in Japan internally (in their own subsidiaries) or externally (selling exploitation rights to independent Japanese firms). A few remarks are necessary for a correct interpretation of the data. First, BOJ's definition of a licensing contract in practice implies that all software, including commodity software packages (e.g. operating software such as UNIX), is included. As a result, more than half of all the licensing contracts in 1994 (1629 out of 3161) concern software, and most of these are mass produced software packages sold to large institutions [Yoshimi 1993, 31)]. One could well argue that the sale of such software packages does not constitute the exploitation of know-how, brand name, or technological advantage, but should rather be included on the trade balance as the sale of commodities. Second, only statistics on the number of contracts are published and there are substantial differences in the value represented by individual contracts. Third, contracts apply for a varying number of years and statistics on new contracts and contract renewals do not necessarily reflect total licensing activity. This latter point is not likely to bias the figures much, since both the number of licensing contracts from the Netherlands (about 80) and the share of the Netherlands in total licensing (about 3 percent) has been remarkably stable throughout the 1990s [NISTEP (1996)].

With the above considerations in mind, Table 6 presents data on the number of new and renewed licensing contracts concluded in 1994 with licensors based in the Netherlands, and compares the numbers with the total number of contracts from all licensor countries. The

${ }^{30}$ In a few areas, such as space technology and weaponry, licensing deals have to be approved by the Japanese government. In the other cases there is only an ex-post reporting requirement. 
number of contracts is desaggregated by product. Firms and individuals in the Netherlands concluded 89 licensing contracts in 1994, which represented 2.8 percent of total licensing contracts signed by residents in Japan with foreign firms. The majority of contracts from all countries concerned computers \& software (1740), a figure which is heavily influenced by the sale of commodity software. In case of Dutch licensing, the share of computers \& software only reached 21 percent. If one excluded the licenses classified under software and computers than the Dutch share in the total number of contracts would be nearer to 5 percent. The distribution of Dutch licenses over product groups is heavily concentrated in the electrical and electronics sector: apart form computers and software, a relatively large number of contracts is classified under radio \& television and VCRs \& medical equipment. As will become clear in paragraph 4.2, this pattern arises because the electronics group Philips dominates Dutch licensing activity in Japan. The other important product group is general machinery (18 percent of contracts) and chemical machinery in particular. Dutch strengths in chemical manufacturing take the form of process technologies and advances in chemical machinery which are exploited in Japan; product-related chemical technologies take an extra 4.5 percent of contracts. Comparing the number of Dutch licenses with the total number by product group confirms the strengths in radio \& television, VCRs \& medical equipment, and chemical machinery. Other product groups with higher than average licensing activity are food, rubber, sports articles \& music, plastic products and building materials. Although not too much weight can be attached to the latter numbers since they are influenced by the very limited licensing activity in general in these product groups, they appear consistent with perceived strengths of Dutch firms in chemical related industries (rubber and plastics), process industries such as food and building materials, and music (Philips subsidiary Polygram).

\section{INSERT TABLE 6}

The licensing data have in common with the FDI data that they include contracts by a number of holding companies and financial subsidiaries established by foreign firms in the Netherlands, which use the Dutch entity to collect the licensing proceeds. On the other hand, the figures do not include licensing contracts signed by Shell and Unilever in the UK and the US subsidiaries of large Dutch MNEs. Also, the 1994 figures in Table 6 cannot be distinguished between intra-firm and arm's length licensing. In paragraph 4.2, both these issues are addressed by examining the available data on individual firms' licensing contracts.

\section{Dutch FDI and Licensing at the Firm Level}


In both the MITI survey data and the FDI data in Paragraph 3.1, the hypothesis of a relatively strong Dutch investment position in Japan is not supported. However, it was also suggested that this may be due to statistical definitions and data imperfections. Micro data on individual Dutch MNEs' investment and licensing activities in Japan are most revealing of Dutch firms' status in Japanese industries. Paragraph 4.1 presents extensive data on Dutch MNEs' subsidiaries in Japan in 1995 and discusses recent developments. Paragraph 4.2 looks at the pattern of licenses sold by Dutch firms in Japan.

\subsection{Main Subsidiaries of Dutch MNEs in Japan}

A detailed picture of Dutch MNEs' presence in Japan can be obtained from data published by Toyo Keizai (1995). This publisher conducts a yearly survey among foreign-affiliated firms in Japan. The 1995 survey among 3432 firms had a response ratio of 86 percent. This compares to a response ratio of MITI's 1994 survey of 50 percent to a questionnaire which effectively reached only 2307 firms. The 86 percent figure still underestimates the coverage of the survey, since non-responses were also due to withdrawals and because the figures were supplemented with information from news reports and other sources. In contrast with the MITI data, Toyo Keizai's coverage can be considered as near complete. The 1995 survey included firms with paid-in capital exceeding 5 million Yen and foreign ownership of at least 50 percent, but the latter threshold was reduced to 20 percent for larger and publicly quoted firms. Table 7 presents key information on most subsidiaries of Dutch MNEs in Japan, based on Toyo Keizai's data and supplemented by a number of other sources and newspaper reports [Dodwell (1988, 1993, 1994)), Keizai Chousakai (1994), Toyo Keizai (1995), Dun \& Bradstreet (1996)]. The Table first lists the subsidiaries of the 'big five' Dutch industrial MNEs with substantial operations in Japan. Ranked by sales in Japan these are Shell, Philips, Unilever, Akzo-Nobel, and DSM. The table continues by listing the main subsidiaries of other Dutch MNEs. If available, information is included on the Dutch investor's equity stake, the equity stake by the Japanese partner, year of establishment or acquisition, capitalisation, sales, declared taxable income, number of employees, imports as a percentage of total procurement, export intensity, function of the subsidiary (manufacturing, distribution, import, export) and lines of business. ${ }^{31}$ It should be noted that the listing is not exhaustive: a number of smaller subsidiaries established by the larger firms (Shell in particular) are not included and neither are a number of smaller Dutch MNEs operating distribution subsidiaries in Japan.

\footnotetext{
31 It is not always clear whether the sales figures reported by Toyo Keizai are on consolidated or unconsolidated basis. In particular in the former case, adding up sales figures will generate an inflated figure for total Japanese sales of the MNE. Employment figures are usually on an unconsolidated basis and may be added up with fewer reservations.
} 


\section{Shell}

Shell has by far the largest presence in Japan among Dutch MNEs, both in absolute as in relative (market share) terms. Shell Transport and Trading, the English predecessor of the Shell group, set up a subsidiary in Japan at the beginning of the twentieth century and was one of the first foreign firms to establish a presence in Japan. Over time, the Shell group has grown into the third largest fully integrated oil company in Japan. Shell's activities are organised around two core companies: Showa Shell Sekiyu and Shell Japan. Showa Shell Sekiyu was created through the 1985 merger of Shell Sekiyu and Showa Sekiyu, both controlled by Shell at the time. Shell maintains a 50 percent stake in the company mainly through Shell UK. It effectively controls Showa Shell since the remaining shares are held in relatively small lots by various investors. Showa Shell had consolidated sales of 1.3 trillion Yen (more than 12 billion US\$) in 1994 and is involved in oil exploration, refining, storage, transportation, distribution and research, while it has also diversified into car rental, software, and real estate. It operates five refineries and 7100 petrol service stations in Japan and has its own marine fleet [Dodwell (1994)]. It is the fifth refiner in Japan and the third gasoline distributor with 12.5 percent of the market [Nihon Keizai Sangyo Shinbun (1996)]. Showa Shell has organised its own vertical keiretsu of 82 subsidiaries and 40 affiliates in different businesses such as exploration (Shoseki Oil Development), distribution (Shoseki Gas, Shoseki Shoji), oil refining (Toa Oil, Showa Yokkaichi Sekiyu), transport (Showa Shell Sempaku), construction (Shoseki Engineering), and production of petrochemicals (Shoseki Kako, Nippon Grease). Showa Shell is also a member of a horizontal keiretsu, the Dai Ichi Kangyo Group, but ties to the group are judged to be relatively weak. Shell's other core subsidiary, Shell Japan, is fully owned by Shell UK and is mainly involved in import, manufacturing and distribution of (petro)chemicals. In 1986, Shell Japan set up a joint venture with Siemens to manufacture solar batteries and solar panels. The total number of employees in Shell subsidiaries, including subsidiaries not listed in Table 7, would easily surpass 6000. Since Shell UK is the investor in both Showa Shell and Shell Japan, none of Shell's investments in Japan enter Dutch FDI statistics. Even in UK statistics, FDI figures are not likely to reflect the size of Shell's operations in Japan very well since most of the investments are by Showa Shell which operates by and large as a Japanese company using equity finance (it is listed at the Tokyo Stock Exchange) as well as local loans to finance its operations.

Shell also had a minority stake in Mitsubishi Oil's subsidiary Mitsubishi Petrochemical, the largest all-round petrochemical maker in Japan. In 1994, Mitsubishi Petrochemical and Mitsubishi Kasei merged to form Mitsubishi Chemical in which Shell maintains a 4 percent 
stake. Cooperation with Mitsubishi Oil is likely to increase. In 1997, Mitsubishi Oil and Showa Shell unveiled plans to merge their refining business, which would create Japan's largest refiner with sales of 16 billion US\$.32 The merger activity follows increasing competition in the Japanese oil industry, which was deregulated in 1996, ending the limitation of import licenses to 29 existing refiners and wholesalers. In the face of declining profitability of operations, US oil distributor Caltex pulled out of its oil refining and distribution joint venture with Nippon Oil. Shell, on the other hand, has shown a commitment to the market and through its strong distribution and marketing arm is well-placed to survive the shakeout in the industry.

\section{Philips}

Philips is the second Dutch investor in Japan in terms of sales and number of employees. Until 1993 it had been the largest investor due to its 35 percent stake in a joint venture with Matsushita, Matsushita Electronics Corporation (MEC), involved in semiconductor, lighting, and cathode ray tube manufacturing. MEC in 1992 employed 22,000 of which 18,000 in Japan. It had semiconductor sales of 1.93 billion US\$ and was the world's tenth largest semiconductor producer. MEC was responsible for 15 percent of turnover of the Matsushita group which is Japan's and the world's largest consumer electronics manufacturer. Philips had set up the joint venture with Matsushita in 1952, because Japan's restrictive legislation on inward investment precluded the establishment of a majority owned manufacturing base. Philips provided MEC with technology for cathode ray tubes and lighting, but MEC's operations remained limited to manufacturing and played no role in increasing penetration of Philips-branded products in Japan. Over time, Matsushita obtained equal or superior technological capabilities in a substantial number of MEC's product lines. Discord arose between Philips and Matsushita on how to implement MEC's overseas expansion, in particular over semiconductor sales and production in the US (where Philips subsidiary Signetics is manufacturing) and cathode ray tube production in China and Europe (where Philips also has its own manufacturing plants). In 1993, Philips, which was troubled by a large debt burden and was in the midst of a painful rationalisation process, indicated it would prefer to pull out of the venture. Matsushita eventually agreed to buy out Philips' stake for 185 billion Yen (about 1.65 billion US\$). The buyout left Matsushita free to pursue its own strategy abroad and to compete head-on with Philips outside Japan, while it left Philips free to

32 Financial Times, 17 February 1997. 
pursue a more independent sales strategy in Japan. ${ }^{33}$ Philips and Matsushita maintained technological links and cross-licensing agreements after the buyout.

Philips also established Philips Japan in the 1950s as a majority owned joint venture with Matsushita. Philips Japan handles imports and distribution of lighting, semiconductors, and small electric appliances. It is also in charge of staffing for Philips subsidiaries in Japan, licensing agreements, and procurement of components and OEM products for Philips factories and distribution subsidiaries overseas. Philips Japan had sales of 117 billion Yen (more than 1 billion US\$) in 1994 but this figure may include procurement in Japan for export. In the late 1980s, Philips acquired Matsushita's remaining stake in the subsidiary.

Philips' major manufacturing subsidiary in Japan is the upmarket audio manufacturer Marantz, listed at the Tokyo Stock Exchange and with a turnover of 44 billion Yen (about 400 million US\$) in 1995. Philips acquired a 50 percent (but controlling) stake in Marantz in 1981 and Marantz has since entered the video equipment market in 1987 (in particular LCD televisions) as well as the telecommunication markets. Including its Japanese manufacturing subsidiaries Standard Communications and Miyako Audio, Marantz employs 1500 in Japan. Marantz is Philips' manufacturing and R\&D base in Japan for audio and video products, but it is exporting a sizeable share of sales abroad and Philips remains an undistinguished player in the Japanese audio and video markets. ${ }^{34}$

Apart from Philips Japan, Philips operates two specialised distribution subsidiaries in Japan. Philips Medical Systems sells diagnostic imaging systems to Japanese hospitals. It had a 1991 turnover of 22 billion Yen (roughly 150 million US\$). Philips is the third largest seller of this type of medical equipment in the world and has managed to obtain a significant market share in Japan. Signetics Japan sells semiconductors and was acquired by Philips through a takeover of US semiconductor manufacturer Signetics. Philips also has semiconductor manufacturing machinery operations in Japan: majority-owned Philips subsidiary ASM manufacturers and sells steppers (etching equipment) for semiconductor manufacturing. This venture again appears to benefit from Japanese manufacturing strengths in semiconductor machinery: operations are not import intensive but of 20 percent of sales is exported.

\footnotetext{
33 See Nikkei Weekly 3 May 1993 and Financial Times 1 May 1993. In 1994 Matsushita acquired a cathode ray tube plant of Nokia in Germany and began production in Europe. Until 1994, Matsushita had relied on tube deliveries from Philips plants in Europe for its European television manufacturing operations.

${ }^{34}$ It has even been reported that Philips would discontinue marketing of consumer electronics products in Japan altogether. Financial Times 14 January 1997.
} 
Philips has been active in extending its manufacturing and marketing presence in Japan. In 1992, it acquired the 70 percent stake which GTE (US) held in a Japanese lighting manufacturer, Kondo Sylvania. ${ }^{35}$ Kondo Sylvania specialises in halogen lamps for studios and optical equipment and has appreciated marketing and technological capabilities. Philips later increased its stake to 100 percent and renamed the company Philips Lighting. Philips Lighting employed 237 in 1995 and had sales of 4.7 billion Yen (about 45 million US\$). All sales are to Philips Japan which handles distribution of its products in Japan and abroad. As with Marantz, the company is export intensive and sells about 40 percent of turnover abroad through Philips Japan.

Philips has also set up a number of (smaller) manufacturing and software joint ventures with Japanese firms. PNN, a joint venture with Nippon Steel and Nippon Chemicon, manufactures ceramic semiconductor packages, Philips Sensor Technology (with Nihon LCR) manufacturers sensors, and Nihon Micromotor (with Foster Electric) manufactures micromotors. Denshi Media Services (with Toppan Printing) and Kyocera and Philips Datanet (with Kyocera) design software. In addition, Philips has business and equity links with two Japanese electronics firms listed at the Tokyo Stock Exchange (not in Table 7): Philips has a small (4.4 percent) stake in Foster Electric (a manufacturer of speakers and microphones) and it has strong business and technical ties with Teikoku Tsushin (a resistor manufacturer) with which it established a manufacturing joint venture in Holland in 1989.

Philips' largest presence in Japan is in music sales. Majority owned subsidiary Polygram operates a number of subsidiaries in Japan engaged in music production, CD manufacturing, and music distribution. Polygram KK is the largest with 1994 sales of 82 billion Yen (more than 700 million US\$). Polygram has increased its marketing efforts and consolidated its business in Japan in the 1990s, giving Polygram KK overall management responsibility over all its Japanese operations. In the early 1990s, Polygram bought out the minority stakes which Matsushita and Matsushita subsidiary JVC had in Polydor KK and Polygram KK. ${ }^{36}$ Polygram is the market leader in music sales world-wide with a 17 percent market share. It has a 13 percent share of the Japanese music market. ${ }^{37}$

A major new development in Philips' Japanese operations occurred in 1996. Philips set up a liquid crystal display (LCD) panel joint venture in Japan with Hosiden, an electronics components maker. Hosiden is one of the smaller players in LCD panel production in Japan

\footnotetext{
35 Nikkei Weekly, 2 January 1992.

${ }^{36}$ Financial Times, 14 January 1994. Polygram KK has also restructured CD manufacturing operations and was the first Japanese music producer to relocate all CD production for the Japanese market to Asia in 1995.

${ }^{37}$ Financial Times, 9 May 1996.
} 
and found it difficult as an independent manufacturer to raise the large amounts of capital necessary to expand production and to secure sales in the increasingly competitive market. Hosiden had LCD panel production worth 180 million US\$ in 1995 and has OEM supply contracts with both Hitachi and NEC. It put its two manufacturing plants in Japan in the joint venture. Philips is a relative latecomer in the LCD panel market. It had developed its own technology to produce diode-based active matrix LCD panels, different from the mainstay thin film transistor active matrix LCDs produced by the leading Japanese firms and Hosiden. Philips started mass production of diode LCDs at its Eindhoven based Flat Panel Display joint venture with Sagem (France), Thomson (France), and Merck (Germany), but has found it difficult to become a significant player in the world market by internal growth only. ${ }^{38}$ The venture with Hosiden will give it the necessary critical mass as well as access to Hosiden's manufacturing skills in thin film transistor LCDs. Philips reportedly paid Hosiden 2 billion Yen for use of its technology in Japan and in the Eindhoven plant, which is likely to switch partly to the mainstay technology. ${ }^{39}$ The size of Philips' investment in the new venture has not been disclosed, but is likely to be substantial given the capital requirements of LCD manufacturing.

A concluding remark on Philips' manufacturing activities in Japan is that an important part of these, in particular in audio and video, halogen lamps, and LCD panels, are more related to the benefits of manufacturing derived from Japan's strong supplier base and R\&D skills in these areas than to particularly strong competitive advantages vis-à-vis Japanese firms. Manufacturing operations have consequently had only limited effects on Philips' market penetration in Japan until now and Philips remains undistinguished in these sectors. Although Philips is the world's largest lighting producer, the joint venture agreements with Matsushita appear to have long precluded it form developing its own marketing strategy in Japan. Philips does enjoy significant market shares for other products in which it has a marketing and technological lead: medical diagnostic equipment, music, and small electrical appliances. ${ }^{40}$

\section{Unilever}

\footnotetext{
38 The Eindhoven Joint venture was producing 40,000 displays a month at the end of 1995. Financial Times, 12 October 1996.

39 The Nikkei Weekly, 25 November 1996

40 Philips' share of the Japanese coffee maker market in 1992 was 10.8 percent. Philips also held 4.5 percent of the shaver market in 1992, but was well behind Matsushita (42 percent) and Braun of Germany (24 percent) [Yano (1994)]. In semiconductors, Philips has been less successful. Its highest share in 1994 was recorded for digital bipolar integrated circuits at 1.9 percent, in sharp contrast with Philips' world market share for digital integrated circuits of more than 11 percent. Philips' share in the overall Japanese semiconductor market only reached 0.37 percent for discrete semiconductors and 0.18 percent for integrated circuits; total sales amounted to 10 billion Yen (about 90 million US\$) [Yano (1995)].
} 
The Anglo-Dutch group Unilever employed about 2000 in Japan in 1995. Group sales reached 90 billion Yen (about 800 million US\$). Unilever's flavouring and aromatic substance subsidiary Quest International made the first advance in Japan and set up a subsidiary in 1963. Unilever itself set up a first joint venture with Honen in the same year (Honen Lever KK) but only later took a majority stake. It assumed full control over the subsidiary in 1986 and the subsidiary was renamed Nippon Lever. Unilever has since then committed itself to the Japanese market and has increased its investments and marketing. It has taken a long term view of its investment and has accepted substantial initial losses on its Japanese operations: Nippon Lever only turned in its first profit in $1993 .{ }^{41}$ It operates two tea manufacturing joint ventures (Japan Black Tea and Lipton Japan) with two of Japan's large trading houses (Mitsui and Mitsubishi), and has a chemicals manufacturing subsidiary (Ablestik). A significant advance in Japan was due to Unilever's acquisition drive in the United States. Unilever acquired the US starch and adhesives maker National Starch and Chemical in 1987 and toiletries and personal care products maker Elisabeth Arden in 1989. Both had substantial Japanese operations which came under control of Unilever: KaneboNSC, NSC Japan, and Elisabeth Arden Japan. ${ }^{42}$ Unilever has carved out significant market shares in Japan in a number of products. After acquiring a margarine brand from Ajinomoto in 1993, it became the second largest margarine producer in Japan with 25 percent of the market. Unilever also has 7 percent of the shampoo market but has been less successful in the detergent market with a 4 percent share (well behind US rival Proctor and Gamble with a 20 percent share [Nihon Keizai Sangyo Shinbun (1996)].

\section{Akzo-Nobel}

AKZO predecessor Organon established a first subsidiary in Japan in 1960, a joint venture with pharmaceutical maker Sankyo engaged in production, import, and distribution of pharmaceuticals. Nippon Organon was still the largest subsidiary of the Akzo-Nobel group in Japan in 1995, with 260 employees and 13 billion Yen (about 120 million US\$) in sales. Akzo-Nobel operates a large number of manufacturing joint ventures and distribution subsidiaries in Japan, each involved in one of the group's different lines of business. Wholly owned Akzo-Nobel KK imports, manufactures, and distributes fine chemicals and is also engaged in R\&D. Three other wholly owned subsidiaries, Akzo Nobel Coatings (car paints), Organon Teknika and Nihon Akzo Pharma (both pharmaceuticals) are engaged in import and

41 Financial Times, 7 May 1992 and 23 February 1994.

42 In a recent development, Unilever sold its speciality chemicals division, including Quest and National Starch and Chemical, to UK chemicals group ICI. Financial Times, 8 May 1997. 
distribution. Two more distribution subsidiaries and seven manufacturing subsidiaries are all joint ventures with local firms. Two joint ventures with Tosoh, Tosoh Akzo and Akzo Kashima, manufacture calcium and titanium, and sulphur and phosphates, respectively. AkzoNobel has important business linkages with Tosoh and also operates an ethylene manufacturing joint venture with the Japanese firms in the Netherlands. Akzo's stake in Tosoh Akzo was acquired in 1987 through a takeover of the speciality chemicals division of US firm Stauffer. Akzo Nobel also manufactures catalysts for oil refining in a joint venture with Sumitomo Metal Mining. This joint venture, Nippon Ketjen, supplies all major refiners in Japan and reportedly has a 35 market share [Toyo Keizai (1995)]. The joint venture with Denki Kagaku Kogyo, Denak, is the largest manufacturer in Japan of monochloroacetic acids. Akzo Nobel manufactures organic peroxide with Nihon Kayaku (Kayaku Akzo), acid derivatives with Lion (Lion Akzo), and paints with Toa Paint (Toa Akzo Coatings). It sells its proprietary aramide fibre through a joint venture with Sumitomo Chemical (Nippon Aramid), plastics through a joint venture with Dainippon Ink and Chemicals (Nihon Interstab), and additives for paper processing industries through a joint venture with Nissan Kagaku (Nissan Eka Nobel).

$D S M$

DSM is the latest entrant to the Japanese market among the largest five Dutch industrial MNEs. It set up its first joint venture in Japan with Japan Synthetic Rubber, Japan Fine Coatings, only in 1982. By 1995 DSM operated at least seven subsidiaries in Japan. With the exception of wholly owned DSM Japan, which has relatively small operations, none of the subsidiaries is majority owned. The largest subsidiary in terms of sales and employment, Nippon Polypenco, came under control of DSM through DSM's acquisition of US manufacturer Polymer (US) in 1989. DSM also makes synthetic rubber with Idemitsu Petrochemical (DSM Idemitsu), fibres and resins with Sankyo Toatsu (MD Composites), polystyrene with Toyobo (Nihon Dyneema), and resins with U-Pica (U-Pica DSM Resins).

\section{Other Dutch Industrial MNEs}

Besides the large five Dutch MNEs, there are only three other Dutch MNEs with manufacturing operations in Japan. Aluminium producer Hunter Douglas operates two joint ventures in Japan which engage in import, manufacturing, and distribution. It produces aluminium panels with Sankyo Aluminium (Hunter Douglas Japan) and blinds with Sekisui Resin (Hunter Douglas Window Fashions) and operates a wholly owned distribution 
subsidiary (Hunter Douglas Metals Japan) as well. Packaging materials group Van Leer has been active in Japan since 1963 (Tri Sure Japan) but until recently did not manufacture in Japan. In 1996 this situation changed when Van Leer invested 34 million US\$ in greenfield manufacturing operations for its mainstay steel drums. It aims to manufacture 1 million drums a year and capture 8 percent of the Japanese market. A major customer will be the Shell group, which Van Leer supplies in other parts of the world as well. Although Van Leer is the world's largest producer of steel drums for the oil and chemical industries and has an extensive network of manufacturing plants world-wide, it has until now not been able to sell significant numbers in Japan. The company cited difficulties in entering the Japanese market, which is dominated by the affiliates of the large Japanese steel makers. It apparently was not able to forge a link with a steel products manufacturer because of pressure from the large Japanese steel suppliers and has had to keep the source of steel supplies for the new plant secret. ${ }^{43}$ A number of other Dutch firms operate distribution subsidiaries in Japan. Heineken has a joint venture with Japanese market leader Kirin Beer. Heineken Japan had a turnover of 2.9 billion Yen (roughly 25 million US\$) in 1994. Heineken has changed its strategy in Japan in the early 1990s. Until 1993, Kirin was the sole distributor of Heineken beer and was producing Heineken beer under license. From 1993, Heineken has shifted to imports to bypass high production costs in Japan, has renegotiated the distribution contract with Kirin, and has started a marketing campaign targeting a doubling of sales in 1995 [Toyo Keizai (1995)]. Instrument manufacturer Delft instruments, machinery manufacturer Stork, and dairy products manufacturer Friesland Frico Domo are among the Dutch MNEs with sales subsidiaries in Japan. Friesland Frico Domo has the largest operations and has also licensed production of cheese to Japanese manufacturers. According to Dun and Bradstreet (1996), subsidiaries are also operated by machinery manufacturer Greenland, steel manufacturer Hoogovens, chemical firm Norit, paper and packaging group BT-KNP, and engineering firm Fugro (not in Table 7).

\section{MNEs in Services}

The largest Dutch financial group, the Internationale Nederlanden Group (ING), has built up substantial operations in Japan since entering the market in 1984. In 1984 it established Nationale Nederlanden Life Insurance. It obtained a license to sell life insurance policies from MOF in 1986. It has gradually increased sales in Japan and in 1995 employed 363 in its life insurance subsidiary. Its banking subsidiary in Japan, ING Bank, has assets of 275 billion Yen (2.5 billion US\$) and employs 71. In addition, in 1996 it acquired the securities and investment banking group Barings in the United Kingdom and took control over Barings'

43 Financial Times, 7 November 1996. 
Japanese operations (not in Table 7). The other major Dutch banking group, ABN-Amro employs 150 in Japan. Its banking subsidiary has substantial assets totalling 1186 billion Yen (about 10 billion US\$). In 1997 it boosted its securities trading and investment banking business in Japan by acquiring the stock brokering license of a Japanese security dealer and ABN-Amro is planning to increase its activities in this area substantially. In the transport sector, Dutch shipping firm Nedlloyd operates one of the larger subsidiaries in Japan with 140 employees, and a second subsidiary with 30 employees. Nedlloyd is likely to increase its presence in Japan after it merged its international shipping business with $\mathrm{P} \& \mathrm{O}$, creating the world's largest shipping group. Dutch international trading firms Borsumij Wehry, Van Ommeren, and Hagemeyer all operate trading subsidiaries in Japan. Borsumij Wehry set up its main subsidiary in Japan, Geo Wehry International, as early as 1955 and employs 47. The subsidiary specialises in the import business and is not exporting from Japan. Reed Elsevier has publishing operations in Japan for professional and academic medical journals, in which the group is world leader. The most recent entry in Japan is by fast expanding business software house Baan, which set up a subsidiary in 1995 employing 39. In addition, the Dutch privatised telecommunications and postal services provider KPN gained a foothold in Japan through its acquisition of Australia's TNT. TNT, a major provider of international parcel and mail service for businesses, operated a subsidiary (TNT World-wide Express Japan) with 290 employees in Japan in 1995.

Apart from the two main financial groups and Nedlloyd, the presence of Dutch MNEs other than the large five industrial concerns is very limited. Indeed a large number of Dutch MNEs with substantial operations in Europe and North America are entirely or almost entirely absent from Japan. The list includes food and drink manufacturers Bols Wessanen, Meneba, and Nutricia, chemical and pharmaceutical producer Gist Brocades, copier and printing machinery manufacture Océ van der Grinten, retail and wholesale groups Vendex, Ahold, and SHV, transport firms Internatio Muller and Pakhoed, construction firms Ballast Nedam, HBG, Boskalis and Volker Stevin, publishers Kluwer and VNU, and financial group Fortis. ${ }^{44}$

\section{Concluding Remarks}

The evidence in this paragraph has revealed a number of features of the operations of Dutch MNEs in Japan. These operations are much more extensive than FDI flow and stock

44 Building group Ballast Nedam set up a subsidiary with Penta Ocean Construction to develop business in underwater construction in 1980 but this subsidiary appears to have been liquidated. Similarly, a pharmaceuticals joint venture between Gist Brocades and Chugai set up in 1984 is no longer recorded in the listings provided by Dun and Bradstreet (1996) and Toyo Keizai (1995). 
data suggest. As predicted, Dutch operations in Japan are dominated by the largest five MNEs: these firms were responsible for more than 90 percent of the 12,000 employees in Dutch controlled subsidiaries identified in Table 7. The dominance of the largest firms is much stronger compared with Dutch FDI in Europe or North America where the 'second tier' Dutch MNEs have made substantial advances as well. Many of the smaller MNEs have ignored the Japanese market. In fact, even a large part of the Japanese expansion of AkzoNobel, Unilever, and DSM has been a by-product of their acquisition drive in the United States. Although the Japanese interests of these US acquisitions are likely to have played a role in their investment decisions, it shows that Dutch firms generally have not focused their international expansion strategy on Japan. The Dutch investment pattern reflects the historical and present barriers to inward investment and the difficulty of direct acquisitions in particular, as described in Section 2. Only Shell with its historic presence in Japan has been able to expand its Japanese business in the immediate post war years, because Japan needed to secure oil supplies and this necessitated close cooperation with the leading oil companies. Philips, in contrast, was forced to enter into a minority joint venture with its later rival Matsushita and this has not helped it much in increasing its market presence in Japan.

The investment patterns show important differences in market entry strategies of the larger MNEs. DSM and Akzo-Nobel operate a range of manufacturing joint ventures with Japanese partners. The joint ventures aim to sell in Japan but also often function as an export platform for Asian markets. Unilever operates wholly or majority owned subsidiaries and has invested in distribution and marketing to increase market share of its branded products in Japan. Philips' strategy is to create stronger links with the Japanese electronics manufacturing base and to benefit from Japanese R\&D and manufacturing strengths. It has acquired stakes in three Japanese companies with important technological and design expertise and has set up a number of high technology joint ventures as well. A high share of its manufacturing output in Japan is sold in Europe and North America. Another observation is that in areas in which Dutch firms are world market leaders, they have often set up manufacturing or have distribution affiliates in Japan which have captured a significant share of the Japanese market. Shell is the best example; others are Philips in small electrical appliances, diagnostic equipment and music, Akzo-Nobel in monochloroacetic acids and catalysts for oil refining, Unilever in margarine, Elsevier in medical journals, and only very recently, Van Leer in steel drums. Finally, Dutch firms are also reaping benefits from the greater opportunities for foreign firms in the Japanese market in the mid 1990s. Philips has succeeded in two acquisitions and has bought out Japanese partners in a number of majority ventures, Shell is planning a merger to become the largest oil refiner in Japan and to consolidate its integrated oil business in the wake of deregulation, and Baan and Van Leer made new entries in Japan. 


\subsection{Licensing Contracts by Individual Dutch MNEs}

Licensing data may throw further light on strategies of Dutch firms in Japan. By distinguishing between intra-firm licensing contracts and arm's length contracts, it is possible to determine the role of internalisation versus externalisation of intangible assets. The STA in the past has published a yearly volume containing licensing data by foreign licensor and Japanese licensee. Unfortunately stopped the publication of individual contract was discontinued in 1987. In this paragraph, the licensing behaviour of Dutch multinationals in Japan is examined during the last five-year period for which contracts data are available 1981-1986. Despite the time lag, these data reveal long term differences in firm strategies which complement the findings based on subsidiary data.

During the five year period 1981-1986, MOF recorded 180 licensing contracts between Dutch firms and resident firms in Japan. In addition, during 1981-1986, 50 extra licenses were sold by foreign subsidiaries of Dutch MNEs, mainly located in the UK and US. The number of 180 Dutch licenses, on the other hand, included about 30 licenses by foreign holding companies in the Netherlands. The Dutch subsidiary of US biotechnology firm Biogen was responsible for 12 more licenses. As with FDI, Dutch licensing activity was dominated by the larger MNEs.

Table 8 presents key data on the number and characteristics of licenses by firm. Philips sold by far the largest number of licenses in Japan: 108 of which 4 by Philips in the US, and 17 by Polygram Germany. Six licenses involved Philips group firms as licensees, of which three licenses were to Marantz. Among the major licensees were large electronics firms such as Toshiba and Sanyo Electric. The licenses were strongly concentrated around compact disk (CD) technology: 7 concerned the disks, 24 the (plastic) cases for the disks, and 39 concerned CD players. These numbers reflect Philips' hold on a number of major CD patents after pioneered CD technology with Sony. Licensing in this case not only generates revenue but also has the important objective to promote standardisation and increase the market potential of CD hardware and music. The strength of Philips' licensing activity reflects the group's technological strength in hardware: software (3 licenses) and trademarks (2 licenses, to Marantz) are much less important.

The second largest licensor is the Shell group with 41 licenses. As with FDI, most of Shell's activities in Japan are controlled from the UK: Shell Research and Shell International Petroleum were responsible for 25 licenses. More than half of the licenses (23) were intrafirm, reflecting Shell's large and established operations in Japan and a choice to exploit its 
technology in-house. Almost half the licensing activity concerned chemical machinery and processes and 10 licenses involved petrochemical products.

Unilever's small number of licenses (7) is due to a concentration of activities in low technology (but marketing intensive) industries. Four of the seven licenses involved tea processing technology and trademarks from its Lipton subsidiary in the UK. All but one license was to Unilever firms in Japan. This reflects a long term strategy to build up its market shares of branded goods by exercising control over its Japanese operations (as seen in the previous paragraph). Also at considerable distance behind Philips and Shell, Akzo sold 9 licenses in Japan, of which only 1 was a (general know how) license to an Akzo subsidiary (Lion Akzo). The technologies involved are varied: paint, chemical machinery, rubber processing technology, and plastics. One trademark was licensed. The licensing pattern of DSM is similar. There were no intra-firm licenses among the 5 recorded contracts, which is congruent to DSM's limited presence in Japan in particular in the early 1980s. One other technology-based Dutch MNE has multiple licensing contracts: pharmaceuticals and yeast producer Gist Brocades sold 5 licenses in Japan. The firm has chosen to sell its know how rather than investing in Japan and does not operate a Japanese subsidiary. Other Dutch firms with licensing activity in Japan include the national air carrier KLM (1), wholesaler SHV (1), dairy producer Frico Domo (1), glass manufacturer Smit Ovens Nijmegen (3), oil exploration engineers Marine Structure Consultants (4), machinery manufacturer Stork (1), building materials manufacturer Schokbeton (1), and engineering firm Fugro (1 license to its Japanese subsidiary).

\section{Conclusions}

Dutch multinationals' investment and operations in Japan reflect the particular regulatory and economic conditions which have affected inward FDI in Japan at large. Japan's level of inward FDI is low by any standard, though not as low as conventionally used statistics suggest. There are, however, important differences in foreign penetration across industries, which are in line with perceived competitive advantages of foreign firms. Another feature of inward FDI is its concentration in joint ventures as opposed to wholly owned operations and acquisitions. The main reason for these stylised facts is the legacy of almost three decades of prohibition and strict regulation of inward investment. Locational disadvantages and a range of entry barriers affecting foreign and Japanese entrants alike (such as vertical integration of manufacturers in the distribution sector) have kept inward investment growing at only a low pace during the 1980s. Deregulation and the prolonged recession of the 1990s have transformed the investment climate in Japan to an important extent in the mid 1990s, as a 
result of which new FDI and in particular acquisitions by foreign firms, have shown unprecedented advance.

The persistent barriers to FDI in Japan are likely to have discouraged smaller MNEs with fewer financial and managerial resources to enter the Japanese market. Consequently one would expect that Dutch FDI, dominated by five large industrial MNEs with substantial world-wide resources, would be relatively less affected in Japan. Figures on Dutch FDI flows and stocks appear to suggest otherwise: they indicate a very limited investment position of Dutch MNEs in Japan commensurate to limited levels of Dutch exports to Japan. However, comparison with survey data on foreign-affiliated firms in Japan highlights that FDI figures give a misleading picture of the extent of Dutch MNEs' operations in Japan, primarily because bilateral investment flows are not always picking up investments by Dutch firms. Survey data identify a large number of subsidiaries of Dutch MNEs which in all employ at least 12,000 in 1995. The largest group, Shell, had sales exceeding 12 billion US\$ in Japan, but none of the group's Japanese assets are recorded in Dutch FDI statistics. As expected, Dutch MNEs' FDI in Japan is dominated by the five largest industrial groups which a share of over 90 percent on an employment basis. Other MNEs with a significant presence in Japan are shipping firm Nedlloyd and financial groups ABN-Amro and ING. The operations of Dutch MNEs in Japan are on the whole profitable, which is in line with the overall performance of foreign-affiliated firms in Japan. On the other hand, Dutch subsidiaries are uncharacteristic in terms of import and export behaviour. Survey data suggest that Dutch affiliates export more from Japan than they import, and there is evidence that this trade imbalance is even larger with the Netherlands. This is a result of the export intensive Japanese manufacturing operations of a number of subsidiaries in particular in the electronics and speciality chemicals sectors, and the fact that affiliates in Japan are also involved in procurement of high technology components and materials for world-wide operations of Dutch MNEs (in particular in case of Philips). Statistics on Dutch licensing activity in Japan in 1994 highlight Dutch firms' technological strengths in chemical machinery and processes and consumer and applied electronics.

Analysis of individual MNEs' subsidiaries and licensing operations reveals a diversity of investment strategies. Early entrant Shell has grown into a large integrated and diversified oil firm in Japan and is pursuing the exploiting its refining and chemical technologies and its access to oil in its Japanese operations. Unilever, operating in the low technology but marketing intensive food and personal care industries, has invested in wholly or majority owned operations to increase market access for its branded products. Both of these groups' licensing activities in Japan show a high share of intra-group contracts. On the other hand, chemical manufacturers Akzo-Nobel and DSM have set up a broad range of manufacturing joint ventures with different Japanese partners. These manufacturing ventures improve access 
to the Japanese market but are also exporting to the rest of Asia. Licensing contracts by these two chemical groups are mainly with independent Japanese firms. The Japanese manufacturing subsidiaries of Philips export relatively high shares of turnover to Europe and the United States and activities are concentrated in sectors where Philips does not hold significant market shares in Japan (such as lighting and audio \& video). Philips uses its Japanese manufacturing base to establish and improve linkages with the strong local supply base and the local $R \& D$ infrastructure. It does generate substantial income from licensing agreements with Japanese firms: it was responsible for two thirds of the number of Dutch licensing contracts in the first half of the 1980s. Its licensing activity mostly reflects its possession of major compact disk patents and know how. Philips does command significant market share in a number of markets where it is world leader, such as medical diagnostic equipment, music, and small electrical appliances. Other firms have also been able to translate their strengths into a substantial presence in Japan: besides Shell in the oil sector the list includes Akzo-Nobel in monochloroacetic acids and catalysts for oil refining, Unilever in margarine, Elsevier in medical journals, ING in life insurance, and Nedlloyd in shipping.

A number of Dutch firms are poised to benefit from the greater opportunities to foreign firms in the Japanese markets of the mid 1990s. Philips acquired two LCD panel manufacturing plants of OEM manufacturer Hosiden, Heineken has reduced its dependence on market leader Kirin with the aim to increase its Japanese sales, Shell is planning a tie-up with Mitsubishi Oil to become the largest refiner in Japan, and software house Baan en packaging group Van Leer both made new entries in Japan. What remains striking, though, is the complete or near absence from Japan of a large number of Dutch MNEs which have been very active in expanding in Europe and the United States. Even an important share of the growth in Japanese operations of Unilever, Akzo-Nobel, and DSM has been a by-product of their US acquisitions, which brought US firms' Japanese subsidiaries under their control. The new opportunities for market entry and acquisitions in Japan demonstrated by the experience of a number of Dutch firms and pioneers such as Toys R Us warrant a much greater focus on the Japanese market by Dutch MNEs than has been the case until today.

\section{References}

Bailey, D., G. Harte and R. Sugden (1992) Japan - a legacy of obstacles confronts foreign investors, Multinational Business, Vol 2, pp27-36

Barkema, H. G., J. H. J. Bell and J. M. Pennings (1996) Foreign Entry, Cultural Barriers and Learning, Strategic Management Journal, Vol 17, pp151-166 
Batzer, E. and H. Laumer (1989) Marketing Strategies and Distribution Channels for Foreign Companies in Japan, Munich, Federal Republic of Germany: IFO Institute for Economic Research

Belderbos, R. A. and P. Holmes (1995) An Economic Analysis of Matsushita Revisited, Antitrust Bulletin, Vol 40, pp825-857

Belderbos, R. A. and L. Sleuwaegen (forthcoming) Tariff Jumping FDI and Export Substitution: Japanese Electronics Firms in Europe, International Journal of Industrial Organisation

De Nederlandsche Bank (DNB) (1990) Kwartaalbericht 1989/4, Amsterdam: De Nederlandsche Bank

De Nederlandsche Bank (DNB) (1996) Kwartaalbericht 1996/3, Amsterdam: De Nederlandsche Bank

De Nederlandsche Bank (DNB) (1996) Jaarverslag 1996, Amsterdam: De Nederlandsche Bank

Dodwell $(1988,1994)$ Industrial Groupings in Japan, Tokyo: Dodwell Marketing Consultants

Dodwell (1993) The Structure of the Japanese Electronics Industry, Tokyo: Dodwell Marketing Consultants

Dun and Bradsteet (1996) Who Owns Whom 1995, Washington, DC: Dun and Bradsteet

Dunning, J. H. and R. Narula (1994) Transpacific Foreign Direct Investment and the Investment Development Path: The Record Assessed, Essays in International Business No 10, The University of South Carolina

Eaton, J. and A. Tamura (1994) Bilateralism and Regionalism in Japanese and US Trade and Direct Foreign Investment Patterns, Journal of the Japanese and International Economies, Vol 8, pp478-510

Encarnation, D. J. (1993) A Common Evolution? A Comparison of United States and Japanese Transnational Corporations, Transnational Corporations, Vol 2, pp 7-31

Japan Development Bank (1997) An Analysis of Foreign Direct Investment and Foreign Affiliates in Japan, Tokyo: Japan Development Bank

JETRO (1996) JETRO White Paper on Foreign Direct Investment 1996 - Summary, Tokyo: JETRO

JETRO (1996) Sekai to Nihon no Kaigai Chokusetsu Toushi 1996 (The World's and Japan's

Direct Foreign Investment 1996), Tokyo: JETRO 
JETRO (1997) JETRO White Paper on International Trade 1996 - Summary, Tokyo: JETRO

Keizai Chousa Kyoukai (1988, 1994) Gaikoku Shihon no Tainichi Toushi (Foreign Investment in Japan), Tokyo: Keizai Chousa Kyoukai

Kim, W. S. and E. O. Lyn (1987) Foreign Direct Investment Theories, Entry Barriers and Reverse Investments in US Manufacturing Industries, Journal of International Business Studies, Vol , pp53-66

Kogut, B. and S.-J. Chang (1991) Technological Capabilities and Japanese Foreign Direct Investment in the United States, Review of Economics and Statistics, Vol 73, pp400-413

Lawrence, R. Z. (1992) Japan's Low Level of Inward Investment: The Role of Inhibitions on Acquisitions, Transnational Corporations, Vol 1, pp47-75

Mason, M. (1995) Japan's Low Levels of Inward Direct Investment: Causes, Consequences and Remedies, in E. Chen and P. Drysdale, eds., Corporate Links and Foreign Direct Investment in Asia and the Pacific, Pymble: Harper Collins, pp129-152

Ministry of Finance (MOF), 1995, Zaisei Kinyuu Tokei Geppou (Financial Investment Statistics Monthly), no 524, December 1995.

Ministry of International Trade and Industry (MITI) (1992, 1995a) Gaishikei Kigyou no Doukou (Foreign Firms in Japan) No 25, Tokyo: Oukurashou Insatsu Kyoku

Ministry of International Trade and Industry (MITI) (1995b) Wagakuni Kigyou no Kaigai Jigyou katsudou (Report on the Foreign Activities of Japanese Corporations), Tokyo: Okurashou Insatsukyoku

Ministry of International Trade and Industry (MITI) (1996) Tsuushou Hakusho (White Paper on International Trade), Tokyo: Oukurashou Insatsu Kyoku

Nakamura, Y., K. Fukao and M. Shibuya (1995) Tainichi Chokusetsu Toushi (Foreign Investment in Japan), Discussion Paper \#95-DOJ-63, Research Institute of International Trade and Industry

National Institute for Science and Technology Policy (NISTEP) (1996) Gaikoku Gijutsu Dounyuu no Doukou Bunseki (Analysis of Technology Imports) , Tokyo: National Institute for Science and Technology Policy

Nieuwkerk, M. v. (1985) De Investeringspositie van Nederland (The Investment Position of the Netherlands), Deventer: Kluwer 
Nihon Keizai Sangyou Shinbun (1996) Shijou Senyuuritsu 1995 (Market Shares 1995),

Tokyo: Nihon Keizai Shinbunsha

Odagiri, H. (1992) Growth through Competition, Competition Through Growth: Strategic

Management and the Economy in Japan, Oxford: Clarendon Press

Odagiri, H. and A. Goto (1996) Technology and Industrial Development in Japan: Building

Capabilities by Learning, Innovation and Public Policy, Oxford: Clarendon Press

Ryans, A. B. (1988) Strategic Market Entry Factors and Market Share Achievement in Japan, Journal of International Business Studies, Vol , pp380-400

Sanna-Randaccio, F. (1996) New protectionism and multinational companies, Journal of International Economics, Vol 41, pp29-51

Science and Technology Agency (STA) (1982-1987) Gaikoku Gijutsu Dounyuu Nenji Houkoku (Report on the Import of Technology) Fiscal Years 1980-1985, Tokyo: STA

Toyo Keizai (1986, 1995) Gaishikei Kigyou Souran (Foreign Affiliated Companies in Japan),

Tokyo: Touyou Keizai Shimpousha

Wakasugi, R. (1995) On the Causes of Low Levels of FDI in Japan, in E. Chen and P.

Drysdale, eds., Corporate Links and Foreign Direct Investment in Asia and the Pacific, Pymble: Harper Collins, pp112-128

Weinstein, D. E. (1996a) Foreign Direct Investment and Keiretsu: Rethinking US and Japanese Policy, Working Paper No 5612, NBER

Weinstein, D. E. (1996b) Structural Impediments to Investment in Japan: What Have We Learned over the Last 450 Years?, in M. Yoshitomi and E. Graham, eds.,Foreign direct investment in Japan, Cheltenham: Edward Elgar, pp136-172

Williamson, P. J. (1993) The One Way To Fight the Japanese: An Assessment of the Threat and Some Appropriate Corporate Responses, Multinational Business, Vol 4, pp1-13

Yano Keizai Kenkyuujo (1994) Nihon Market Share Jiten (Japan Market Share Handbook),

Tokyo: Mitsutomosha

Yano Keizai Kenkyuujo (1995) 1995 Handoutai Shijou no Chuuki Yosoku Forecasts (1995

Semiconductor Market Short and Medium Term), Tokyo: Mitsutomosha

Yoshimi, K. (1993) Statistics of Japan's Trade in Technology: Quantitative Analysis Approach, NISTEP Study Material No 26, National Institute of Science and Technology Policy 
Yoshitomi, M. and E. M. Graham, eds. (1996) Foreign direct investment in Japan, Cheltenham, U.K.: Edward Elgar 
Table 1. Japan's FDI Imbalance in Perspective: FDI Flows 1990-1994 for Selected Countries (mln \$)

\begin{tabular}{|c|c|c|c|c|c|c|}
\hline & 1990 & 1991 & 1992 & 1993 & 1994 & 1990-1994 \\
\hline \multicolumn{7}{|l|}{ Japan } \\
\hline Outward & 48050 & 30740 & 17240 & 13740 & 17790 & 127560 \\
\hline Inward & 1760 & 1370 & 2720 & 100 & 890 & 6840 \\
\hline Ratio & 27.3 & 22.4 & 6.3 & 137.4 & 20.0 & 18.6 \\
\hline \multicolumn{7}{|l|}{ United States } \\
\hline Outward & 29950 & 31380 & 42660 & 72590 & 49380 & 225960 \\
\hline Inward & 47920 & 22020 & 17580 & 41110 & 49420 & 178050 \\
\hline Ratio & 0.6 & 1.4 & 2.4 & 1.8 & 1.0 & 1.3 \\
\hline \multicolumn{7}{|c|}{ United Kingdom } \\
\hline Outward & 19327 & 16304 & 18892 & 25671 & 25334 & 105528 \\
\hline Inward & 32430 & 16208 & 14934 & 14475 & 10085 & 88132 \\
\hline Ratio & 0.6 & 1.0 & 1.3 & 1.8 & 2.5 & 1.2 \\
\hline \multicolumn{7}{|l|}{ Germany } \\
\hline Outward & 24210 & 23720 & 19670 & 14480 & 14650 & 96730 \\
\hline Inward & 2490 & 4070 & 2440 & 320 & -3020 & 6300 \\
\hline Ratio & 9.7 & 5.8 & 8.1 & 45.3 & -4.9 & 15.4 \\
\hline \multicolumn{7}{|l|}{ France } \\
\hline Outward & 34882 & 23932 & 31269 & 20604 & 22800 & 133487 \\
\hline Inward & 13183 & 15149 & 21843 & 20755 & 17138 & 88068 \\
\hline Ratio & 2.6 & 1.6 & 1.4 & 1.0 & 1.3 & 1.5 \\
\hline \multicolumn{7}{|l|}{ Netherlands } \\
\hline Outward & 15388 & 13561 & 14338 & 10555 & 11366 & 65208 \\
\hline World share & 7 & 7 & 8 & 5 & 6 & 6 \\
\hline Inward & 12349 & 6316 & 7700 & 6084 & 3473 & 35922 \\
\hline Ratio & 1.2 & 2.1 & 1.9 & 1.7 & 3.3 & 1.8 \\
\hline World & 235529 & 195233 & 190030 & 208456 & 203229 & 1032477 \\
\hline
\end{tabular}


Table 2. Japan's FDI Imbalance: Number of Employees in Foreign-Affiliated Firms in Japan and in Japanese-Affiliated Abroad, 1994.

\begin{tabular}{|c|c|c|c|c|c|c|c|c|c|}
\hline \multirow[t]{2}{*}{$\begin{array}{r}\text { Investing Country: } \\
\text { Host Country: }\end{array}$} & \multirow{2}{*}{$\begin{array}{r}\text { Japan } \\
\text { US } \\
252277\end{array}$} & \multicolumn{2}{|c|}{$\begin{array}{c}\text { US } \\
\text { Japan Balance }\end{array}$} & \multirow{2}{*}{$\begin{array}{r}\text { Japan } \\
\text { Europe } \\
148136\end{array}$} & \multicolumn{2}{|c|}{$\begin{array}{l}\text { Europe } \\
\text { Japan Balance }\end{array}$} & \multirow{2}{*}{$\begin{array}{r}\text { Japan } \\
\text { World }\end{array}$} & \multirow{2}{*}{$\begin{array}{r}\text { World } \\
\text { Japan } \\
139666\end{array}$} & \multirow{2}{*}{$\begin{array}{r}\text { Balance } \\
7.5\end{array}$} \\
\hline & & 99230 & 2.5 & & 30296 & 4.9 & & & \\
\hline Food & 15190 & 3322 & 4.6 & 728 & 185 & 3.9 & 31747 & 3646 & 8.7 \\
\hline Textiles & 3713 & 0 & $\inf$ & 1062 & 1499 & 0.7 & 62491 & 1510 & 41.4 \\
\hline Wood \& paper & 1879 & 477 & 3.9 & 336 & 483 & 0.7 & 10617 & 4226 & 2.5 \\
\hline Chemicals \& pharmaceuticals & 23338 & 26451 & 0.9 & 20241 & 14605 & 1.4 & 61768 & 41682 & 1.5 \\
\hline Oil & 55 & 5789 & 0.0 & 16 & 2399 & 0.0 & 553 & 8228 & 0.1 \\
\hline Steel & 15920 & 0 & $\inf$ & 394 & 1158 & 0.3 & 22234 & 1230 & 18.1 \\
\hline Non-ferrous metals & 4245 & 659 & 6.4 & 495 & 60 & 8.3 & 17086 & 5758 & 3.0 \\
\hline General machinery & 15775 & 10413 & 1.5 & 9901 & 2649 & 3.7 & 70350 & 13093 & 5.4 \\
\hline Electrical \& electronics & 67614 & 46004 & 1.5 & 59820 & 2988 & 20.0 & 435726 & 49163 & 8.9 \\
\hline Transport machinery & 31688 & 1045 & 30.3 & 29482 & 1056 & 27.9 & 160993 & 2129 & 75.6 \\
\hline Precision machinery \& optical & 1699 & 2796 & 0.6 & 1798 & 2004 & 0.9 & 27801 & 4916 & 5.7 \\
\hline Other manufacturing & 71157 & 3180 & 22.4 & 23863 & 2701 & 8.8 & 143028 & 9237 & 15.5 \\
\hline Distribution & 129463 & 9762 & 13.3 & 50714 & 10251 & 4.9 & 236610 & 22749 & 10.4 \\
\hline Services & 15798 & 2438 & 6.5 & 3412 & 1024 & 3.3 & 36929 & 3636 & 10.2 \\
\hline Other non-manufacturing & 12646 & 1435 & 8.8 & 7021 & 1318 & 5.3 & 37212 & 3039 & 12.2 \\
\hline All industries & 410184 & 112865 & 3.6 & 209283 & 42889 & 4.9 & 1355235 & 169090 & 8.0 \\
\hline Response Ratio & 65 & 50 & & 65 & 50 & & 65 & 50 & \\
\hline Ownership & $>50$ & $>33$ & & $>50$ & $>33$ & & $>50$ & $>33$ & \\
\hline
\end{tabular}


Table 3. Subsidiaries of Dutch MNEs in Japan by Industry in 1994

\section{\# Subs \\ Assets Employees}

Manufacturing

Food

Textiles

Wood

Paper

Printing \& publishing

Pharmaceuticals

Oil

Rubber

Leather

building materials

Steel

Non-ferrous metals

Metal products

General machinery

Electrical \& electronics

Transport machinery

Precision machinery \& optical

Other manufacturing

$\%$ all

countries

Sale

$\%$ all Pre-Tax Profits \%

169
325

(billion Yen) Countries

$\begin{array}{rr}212.6 & 2.3\end{array}$

(million Yen) Sales

$6.5-5$

6
0
67

$\begin{array}{rrr}0.2 & 12.4 & 5.2\end{array}$

$\begin{array}{lll}0.0 & 0.0 & 0.0\end{array}$

$\begin{array}{rrr}53.0 & 5.0 & 46.7 \\ 0.9 & 0.0 & 0.0\end{array}$

0

\section{Distribution}

Services

Other non-manufacturing

All industries

Source: MITI (1995b) 
Table 4. Subsidiaries of Dutch MNEs in Japan by Industry in 1991: Exports and Imports

\begin{tabular}{|c|c|c|c|c|c|c|c|c|}
\hline & $\begin{array}{r}\text { Sales } \\
\text { (billion Yen) }\end{array}$ & $\begin{array}{r}\text { Export } \\
\text { (billion Yen) }\end{array}$ & $\begin{array}{l}\text { Export } \\
\text { \% Sales }\end{array}$ & $\begin{array}{r}\text { of which: } \\
\text { Intra-Firm } \\
\%\end{array}$ & $\begin{array}{r}\text { Import } \\
\text { (billion Yen) }\end{array}$ & $\begin{array}{l}\text { Import } \\
\text { \% Sales }\end{array}$ & $\begin{array}{r}\text { of which: } \\
\text { Intra-Firm } \\
\%\end{array}$ & $\begin{array}{r}\text { Trade Balance } \\
\text { (billion Yen) }\end{array}$ \\
\hline Manufacturing & 261.2 & 61.4 & 23.5 & 34.4 & 41.1 & 15.7 & 33.6 & 20.3 \\
\hline Food & 12.2 & 0 & 0.0 & & 0.3 & 2.2 & 99.2 & -0.3 \\
\hline Printing \& publishing & 0.1 & 0 & 0.0 & & 0.0 & 0.0 & & 0.0 \\
\hline Chemicals & 43.6 & 2 & 4.6 & 5.0 & 3.3 & 7.5 & 57.1 & -1.3 \\
\hline Pharmaceuticals & 31.0 & 0 & 0.0 & & 17.5 & 56.5 & 5.2 & -17.5 \\
\hline General machinery & 3.4 & 0.9 & 26.5 & 44.4 & 0.3 & 7.6 & 83.8 & 0.6 \\
\hline Electrical \& electronics & 72.0 & 44.4 & 61.7 & 28.4 & 8.4 & 11.7 & 74.7 & 36.0 \\
\hline Precision machinery \& optical & 25.1 & 13.2 & 52.6 & 60.6 & 7.0 & 28.0 & 44.1 & 6.2 \\
\hline Other Manufacturing & 67.5 & 0.4 & 0.6 & 0.0 & 3.5 & 5.3 & 2.3 & -3.1 \\
\hline Distribution & 612.4 & 149 & 24.3 & 94.6 & 120.7 & 19.7 & 37.5 & 28.3 \\
\hline Services & 22.2 & 0.3 & 1.4 & 0.0 & 5.5 & 24.7 & 100.0 & -5.2 \\
\hline
\end{tabular}


Table 5. Imports and Exports by Subsidiaries of Dutch MNEs: Regions of Origin and Destination in 1991

Manufacturing Affiliates:

North America

Asia

Europe

UK, France, Germany, Switzerland

other countries

Other Regions

Total

\section{Distribution Affiliates:}

North America

Asia

Europe

UK, France, Germany, Switzerland

other countries

Other Regions

Total

Source: MITI (1992)

$\begin{array}{rr}\begin{array}{r}\text { Export } \\ (\%)\end{array} & \text { Import } \\ 30.7 & (\%) \\ 24.3 & 8.5 \\ 41.8 & 22.4 \\ 4.0 & 68.6 \\ 37.8 & 44.2 \\ 3.2 & 24.4 \\ 100.0 & 0.5 \\ & 100.0\end{array}$

$\begin{array}{rr}(\boldsymbol{\%}) & (\boldsymbol{\%}) \\ 9.7 & 6.2 \\ 20.5 & 16.7 \\ 64.5 & 77.1 \\ 13.4 & 51.6 \\ 51.1 & 25.5 \\ 5.3 & 0.0 \\ 100.0 & 100.0\end{array}$

$\begin{array}{rrr}\begin{array}{r}\text { Export } \\ \text { (Billion Yen) }\end{array} & \begin{array}{r}\text { Import } \\ \text { (Billion Yen) }\end{array} & \begin{array}{r}\text { Balance } \\ \text { (Billion Yen) }\end{array} \\ 18.9 & 3.5 & 15.4 \\ 14.9 & 9.2 & 5.7 \\ 25.7 & 28.2 & -2.5 \\ 2.0 & 18.2 & -16.2 \\ 23.7 & 10.0 & 13.7 \\ 1.9 & 0.2 & 1.7 \\ 61.4 & 41.1 & 20.3\end{array}$

$\begin{array}{rrr}\begin{array}{r}\text { Export } \\ \text { Billion Yen) }\end{array} & \begin{array}{r}\text { Import } \\ \text { (Billion Yen) }\end{array} & \begin{array}{r}\text { Balance } \\ \text { (Billion Yen) }\end{array} \\ 14.6 & 7.3 & 7.3 \\ 30.6 & 20.1 & 10.5 \\ 96.1 & 93.1 & 3.0 \\ 20.1 & 53.3 & -33.2 \\ 76.0 & 39.8 & 36.2 \\ 7.8 & 0.1 & 7.7 \\ 149.1 & 120.6 & 28.5\end{array}$


Table 6. Number of Licensing Contracts Imported from the Netherlands in 1994 by Product/Technology

\begin{tabular}{|c|c|c|c|c|}
\hline & $\begin{array}{c}\text { Netherlands } \\
\text { \# contracts }\end{array}$ & $\%$ & $\begin{array}{r}\text { All Countries } \\
\text { \# contracts }\end{array}$ & $\begin{array}{r}\text { Netherlands } \\
\text { Share (\%) }\end{array}$ \\
\hline Manufacturing & 87 & 97.8 & 3112 & 2.8 \\
\hline Food & 2 & 2.2 & 27 & 7.4 \\
\hline Textiles \& apparel & 4 & 4.5 & 193 & 2.1 \\
\hline Wood \& furniture & 0 & 0.0 & 8 & 0.0 \\
\hline Paper, printing \& publishing & 0 & 0.0 & 10 & 0.0 \\
\hline Chemicals & 4 & 4.5 & 80 & 5.0 \\
\hline Pharmaceuticals & 0 & 0.0 & 95 & 0.0 \\
\hline Oil & 0 & 0.0 & 5 & 0.0 \\
\hline Rubber & 1 & 1.1 & 4 & 25.0 \\
\hline Plastics products & 3 & 3.4 & 41 & 7.3 \\
\hline Leather & 2 & 2.2 & 32 & 6.3 \\
\hline Building materials & 2 & 2.2 & 28 & 7.1 \\
\hline Steel & 0 & 0.0 & 12 & 0.0 \\
\hline Non-ferrous metals & 0 & 0.0 & 10 & 0.0 \\
\hline Metal products & 1 & 1.1 & 20 & 5.0 \\
\hline General machinery & 16 & 18.0 & 231 & 6.9 \\
\hline boilers \& generators & 0 & 0.0 & 75 & 0.0 \\
\hline Chemical machinery & 8 & 9.0 & 54 & 14.8 \\
\hline Others & 8 & 9.0 & 102 & 7.8 \\
\hline Electrical \& electronics & 49 & 55.1 & 2092 & 2.3 \\
\hline Heavy electrical equipment & 0 & 0.0 & 12 & 0.0 \\
\hline White goods \& light bulbs & 0 & 0.0 & 7 & 0.0 \\
\hline Telecommunications equipment & 2 & 2.2 & 59 & 3.4 \\
\hline Radio \& television & 17 & 19.1 & 85 & 20.0 \\
\hline Computers \& software & 19 & 21.3 & 1740 & 1.1 \\
\hline Components \& semiconductors & 4 & 4.5 & 125 & 3.2 \\
\hline VCRs, medical electronics & 7 & 7.9 & 55 & 12.7 \\
\hline Others & 0 & 0.0 & 9 & 0.0 \\
\hline Transport machinery & 1 & 1.1 & 33 & 3.0 \\
\hline Precision machinery \& optical & 0 & 0.0 & 90 & 0.0 \\
\hline Other products & 2 & 2.2 & 42 & 4.8 \\
\hline Sports, music & 2 & 2.2 & 22 & 9.1 \\
\hline Others & 0 & 0.0 & 20 & 0.0 \\
\hline Services \& utilities & 2 & 2.2 & 35 & 5.7 \\
\hline All industries & 89 & 100.0 & 3161 & 2.8 \\
\hline
\end{tabular}


Table 7. Main Subsidiaries of Dutch MNEs in Japan, 1995

\begin{tabular}{|c|c|c|c|c|c|c|c|c|c|c|c|c|}
\hline Name & Own & Establ. & Paid-in & Sales & Income & Empl. & Activ. & Imp. & Exp. & Line of Busines & Partner(s) Stake & Remarks \\
\hline & $\%$ & & Capital & & & & & $\%$ & $\%$ & & & \\
\hline \multicolumn{13}{|l|}{ Shell } \\
\hline \multicolumn{13}{|l|}{ Showa Shell Group } \\
\hline Showa Yokkaichi Sekiyu & 75 & 1957 & 4000 & 31201 & 973 & 658 & $\mathrm{M}$ & 0 & 0 & oil products & Mitsubishi Kasei 4.2, others & through Showa Shell \\
\hline Toa Oil & 42 & 1924 & 4961 & 30341 & 1145 & 507 & $\mathrm{M}$ & & 0 & oil products & various & through Showa Shell \\
\hline Nippon Grease & 49.6 & 1941 & 100 & a11677 & & 225 & $\mathrm{M}$ & & & grease, petrochemicals & various & through Showa Shell \\
\hline Shoseki Kako & 100 & 1953 & 200 & 8409 & & 170 & $\mathrm{M}, \mathrm{D}$ & & & asphalt & & through Showa Shell \\
\hline Shoseki Gas & 100 & 1941 & 100 & & & 280 & $\mathrm{D}$ & & & gas distribution & & through Showa Shell \\
\hline Shoseki Engineering & 100 & 1979 & 100 & & & 286 & & & & construction & & through Showa Shell \\
\hline Showa Shell Sempaku & 100 & 1976 & 450 & 41290 & 175 & 18 & & & & transport & & through Showa Shell \\
\hline $\begin{array}{l}\text { Shoseki Oil Development } \\
\text { Vietnam }\end{array}$ & 55 & 1992 & 1827 & & & 15 & & & & oil exporation & Sekiyu Kodan 45 & through Showa Shell \\
\hline \multicolumn{13}{|l|}{ Shell Japan Group } \\
\hline Shell Japan & 100 & 1963 & 12100 & 64100 & 8379 & 350 & $\mathrm{I}, \mathrm{M}, \mathrm{D}, \mathrm{E}$ & 49 & 16 & petrochemicals, LNG & & through Shell (UK) \\
\hline Yuka Shell Epoxy & 59.7 & 1979 & 1200 & & & 135 & $\mathrm{M}$ & & & chemicals & Mitsubishi Chemical & through Shell (UK) \\
\hline Showa Solar Energy & 75 & 1986 & 494 & 1500 & & b37 & $\mathrm{I}, \mathrm{M}, \mathrm{D}, \mathrm{E}$ & 50 & 70 & solar batteries, panels & Siemens 25 & through Shell (UK) \\
\hline & & & & & & & & & & & & \\
\hline \multicolumn{13}{|l|}{ Philips } \\
\hline \multicolumn{13}{|l|}{ Philips Japan Group } \\
\hline Philips Japan & 100 & 1953 & 4000 & 117300 & 2065 & 619 & $\mathrm{I}, \mathrm{D}, \mathrm{E}$ & & & electronics & & \\
\hline Philips Lighting & 100 & 1992 & 50 & 4700 & 260 & 237 & $\mathrm{I}, \mathrm{M}, \mathrm{D}, \mathrm{E}$ & 7. & 40 & halogen, metal halide lamps & & acquired 1992 \\
\hline Philips Medical Systems & 100 & 1987 & 480 & b22000 & & 150 & $\mathrm{I}, \mathrm{D}$ & & & medical equipment & & \\
\hline Philips Mediservice & 100 & 1991 & 110 & & & 80 & $\mathrm{D}$ & & & medical equipment services & & \\
\hline \multicolumn{13}{|l|}{ Marantz Group } \\
\hline Marantz Japan & 50 & 1981 & 1135 & f43897 & 594 & 953 & $\mathrm{M}, \mathrm{D}, \mathrm{E}$ & & 41 & audio, video & various & Acquisition of 50\% stake \\
\hline Miyako Audio & 100 & 1981 & 50 & & & 200 & & & & audio, video & & through Marantz \\
\hline Standard Communications KK & 100 & 1984 & 20 & & & 60 & & & & audio, video & & through Marantz \\
\hline Standard Communications Corp. & 100 & 1981 & 50 & & & 295 & & & & audio, video & & through Marantz \\
\hline \multicolumn{13}{|l|}{ Polygram Group } \\
\hline Polygram KK & 100 & 1990 & 3561 & 82363 & & 320 & $\mathrm{M}$ & & & CDs, audiotapes & & through Polygram (Neth) \\
\hline Polydor KK & 99 & 1953 & 480 & & $\mathrm{~d} 840$ & 100 & $\mathrm{D}$ & & & CDs, video, audiotapes & & through Polygram (Neth) \\
\hline
\end{tabular}




\begin{tabular}{|c|c|c|c|c|c|c|c|c|c|c|c|c|}
\hline Name & Own & Establ. & Paid-in & Sales & Income & Empl. & Activ. & Imp. & Exp. & Line of Busines & Partner(s) Stake & Remarks \\
\hline & $\%$ & & Capital & & & & & $\%$ & $\%$ & & & \\
\hline \multicolumn{13}{|l|}{ Others } \\
\hline ASM Japan & 100 & 1982 & 2900 & & & 125 & $\mathrm{I}, \mathrm{M}, \mathrm{D}, \mathrm{E}$ & 5 & 20 & semiconductor steppers & & through ASM (Neth) \\
\hline Signetics Japan & 100 & 1988 & e60 & E8000 & & & $\mathrm{D}, \mathrm{I}$ & & & semiconductors & & acquisition Signectics (US) 1988 \\
\hline PNN & 40 & 1986 & 1500 & 731 & & 130 & $\mathrm{M}, \mathrm{D}$ & & & ceramic electronic devices & \multicolumn{2}{|c|}{ Nippon Steel 30, Nih. Chemicon 30} \\
\hline Philips Sensor Technology & 50 & 1987 & 180 & & & 23 & $\mathrm{I}, \mathrm{M}, \mathrm{D}, \mathrm{E}$ & 10 & 10 & sensors & Nihon LCR 50 & $R \& D$ focus \\
\hline Nihon Micromotor & 49 & 1979 & 200 & & & e3 & $\mathrm{M}, \mathrm{D}$ & & & micromotors & Foster Electric 51 & \\
\hline Denshi Media Services & 25 & 1987 & 300 & & & 30 & $\mathrm{M}, \mathrm{D}$ & & & CD-I software design & Toppan Printing 75 & \\
\hline Kyocera \& Philips Datanet & 50 & 1985 & 200 & E6000 & & $\mathrm{e} 20$ & $\mathrm{I}, \mathrm{D}$ & & & telecommunications software & Kyocera 50 & \\
\hline Total Philips & & & & & & 3372 & & & & & & \\
\hline & & & & & & & & & & & & \\
\hline \multicolumn{13}{|l|}{ Unilever } \\
\hline \multicolumn{13}{|l|}{ Wholly Owned } \\
\hline Nippon Lever & 100 & 1973 & & f90000 & & 1000 & $\mathrm{M}, \mathrm{D}$ & & & \multicolumn{2}{|c|}{ foodstuffs, detergents, fats and oils } & \\
\hline Ablestik Japan & 100 & 1984 & 34 & & & 39 & $\mathrm{M}, \mathrm{D}$ & & & chemicals & & \\
\hline Quest International Japan & 100 & 1963 & 480 & & & 100 & $\mathrm{I}, \mathrm{M}, \mathrm{D}, \mathrm{E}$ & & & aromatics, flavourings & & \\
\hline Lipton Lever & 100 & 1990 & 50 & & & & $\mathrm{D}$ & & & food, margarine & & \\
\hline Japan Black Tea & 30 & 1973 & 193 & & & 237 & $\mathrm{I}, \mathrm{M}, \mathrm{D}, \mathrm{E}$ & & & tea & Mitsubishi Corp 39, others & \\
\hline Lipton Japan & 70 & 1984 & 300 & & & & $\mathrm{M}, \mathrm{D}$ & & & (Japanese) tea & Mitsui Corp 15, others & \\
\hline \multicolumn{13}{|l|}{ US acquisitions } \\
\hline Kanebo-NSC & 95 & 1987 & 250 & 14128 & 1663 & 350 & $\mathrm{M}, \mathrm{D}$ & 2 & 2 & resins, adhesives & Kanebo 5 & acquisition NSC (US) 1987 \\
\hline Elisabeth Arden Japan & 100 & 1989 & 228 & & & 260 & & & & personal care products & & Acq. Elisabeth Arden (US) 1989 \\
\hline NSC Japan & 100 & 1987 & 50 & & & 27 & $\mathrm{I}, \mathrm{M}, \mathrm{D}, \mathrm{E}$ & 90 & 10 & starch, reinforcing agents & & acquisition NSC (US) 1987 \\
\hline Total Unilever & & & & & & 2013 & & & & & & \\
\hline & & & & & & & & & & & & \\
\hline \multicolumn{13}{|l|}{\begin{tabular}{|l|} 
Akzo-Nobel \\
\end{tabular}} \\
\hline \multicolumn{13}{|l|}{ Manufacturing Joint Ventures } \\
\hline Nippon Organon & 60 & 1960 & 277 & 13000 & 854 & 260 & $\mathrm{I}, \mathrm{M}, \mathrm{D}$ & 100 & 0 & pharmaceuticals & Sankyo 40 & \\
\hline Tosoh Akzo & 50 & 1987 & 500 & 7373 & 1142 & 191 & $\mathrm{M}, \mathrm{D}, \mathrm{E}$ & 0 & 16 & calcium, titanium & Tosoh 50 & acquisition Stauffer (US) 1987 \\
\hline Akzo Kashima & 70 & 1975 & 2000 & & a138 & 147 & $\mathrm{M}$ & 0 & 0 & sulphur, posphate & Tosoh 30 & $R \& D$ \\
\hline Nippon Ketjen & 50 & 1970 & 480 & $c 4000$ & 1401 & 112 & $\mathrm{M}, \mathrm{D}$ & 5 & 20 & oil refining catalysts & Sumitomo Kinzoku Kosan 50 & \\
\hline Lion Akzo & 50 & 1963 & 900 & 8002 & 746 & 104 & $\mathrm{M}, \mathrm{D}$ & & & acid derivatives & Lion 50 & \\
\hline Kayaku Akzo & 50 & 1970 & 400 & & 989 & 100 & $\mathrm{M}, \mathrm{D}$ & & & organic peroxide & Nihon Kayaku 50 & \\
\hline Denak & 50 & 1976 & 1200 & & 134 & 5 & $\mathrm{I}, \mathrm{M}, \mathrm{D}, \mathrm{E}$ & & 50 & monchloroacetic acids & \multicolumn{2}{|c|}{ Denki Kagaku Kogyo 30, Mitsui Toatsu Kagaku 20} \\
\hline
\end{tabular}




\begin{tabular}{|c|c|c|c|c|c|c|c|c|c|c|c|c|}
\hline Name & Own & Establ. & Paid-in & Sales & Income & Empl. & Activ. & Imp. & Exp. & Line of Busines & Partner(s) Stake & Remarks \\
\hline & $\%$ & & Capital & & & & & $\%$ & $\%$ & & & \\
\hline \multicolumn{13}{|l|}{ Wholly owned } \\
\hline Akzo Nobel KK & 100 & 1973 & 2000 & & b119 & 43 & $\mathrm{I}, \mathrm{M}, \mathrm{D}, \mathrm{E}$ & & & chemicals & & $\begin{array}{l}\text { merged with Stauffer Japan in } \\
1988\end{array}$ \\
\hline Akzo Nobel Coatings & 100 & 1984 & 230 & & & 60 & $\mathrm{I}, \mathrm{D}$ & 100 & & car paints & & \\
\hline Organon Teknika & 100 & 1979 & 169 & & & 50 & $\mathrm{I}, \mathrm{D}$ & & & pharmaceuticals & & \\
\hline Nihon Akzo Pharma & 100 & 1975 & 230 & & & & $\mathrm{I}, \mathrm{D}$ & & & pharmaceuticals & & \\
\hline \multicolumn{13}{|c|}{ Distribution Joint Ventures } \\
\hline Nippon Aramid & 50 & 1987 & 200 & & & 13 & $\mathrm{I}, \mathrm{D}$ & 100 & 0 & aramid & Sumitomo Kagaku 50 & \\
\hline Nissan-Eka Nobel & 50 & 1986 & 120 & & & 8 & $\mathrm{I}, \mathrm{D}$ & 60 & 0 & paper processing agents & Nissan Kagaku Kogyo 50 & through Eka Nobel (Sweden) \\
\hline Nihon Interstab & 50 & 1972 & 30 & & & & $\mathrm{I}, \mathrm{D}$ & & & plastic materials & Dainippon Ink Chemicals 50 & \\
\hline Total Akzo & & & & & & 1093 & & & & & & \\
\hline & & & & & & & & & & & & \\
\hline \multicolumn{13}{|l|}{ DSM } \\
\hline \multicolumn{13}{|c|}{ Manufacturing Joint Ventures } \\
\hline Nippon Polypenco & 45 & 1989 & 240 & c4873 & 247 & 107 & $\mathrm{M}, \mathrm{D}$ & 4 & 0 & engineering plastics, nylon & Mitubishi Resin 55 & acquisition Polymer (US) 1989 \\
\hline DSM Idemitsu & 50 & 1988 & 4700 & $\mathrm{~d} 2870$ & & 100 & $\mathrm{I}, \mathrm{M}, \mathrm{D}, \mathrm{E}$ & 0 & 50 & synthetic rubber & Idemitsu Chemical 50 & exports to Asia \\
\hline MD Composites & 50 & 1992 & 800 & & & & $\mathrm{M}$ & & & artificial fibers, resins & Sankyo Toatsu Kagaku 50 & \\
\hline \multicolumn{13}{|l|}{ Wholly Owned } \\
\hline DSM Japan & 100 & 1990 & 40 & & & 10 & $\mathrm{M}, \mathrm{D}$ & & & resins, chemicals & & \\
\hline \multicolumn{13}{|c|}{ Distribution Joint Ventures } \\
\hline Japan Fine Coatings & 50 & 1982 & 92 & 2556 & 443 & 1 & $\mathrm{I}, \mathrm{D}, \mathrm{E}$ & 5 & 10 & coatings for plastic \& paper & Japan Synthetic Rubber 50 & \\
\hline U-Pica DSM Resins & 50 & 1991 & 20 & & & & $\mathrm{I}, \mathrm{D}$ & & & resins & Nihon U-Pica 50 & \\
\hline Total DSM & & & & & & 223 & & & & & & \\
\hline & & & & & & & & & & & & \\
\hline \multicolumn{13}{|c|}{ Other Dutch Industrial MNEs } \\
\hline & & & & & & & & & & & & \\
\hline \multicolumn{13}{|l|}{ Heineken } \\
\hline Heineken Japan & 51 & 1983 & 200 & 2920 & & 60 & $\mathrm{I}, \mathrm{D}$ & 60 & & beer & Kirin (49) & \\
\hline \multirow{2}{*}{\multicolumn{13}{|c|}{ Friesland (Frico Domo) }} \\
\hline & & & & & & & & & & & & \\
\hline Foremost Blue Seal & 100 & 1963 & 152 & & & 50 & $\mathrm{I}, \mathrm{D}$ & & & dairy products & & \\
\hline & & & & & & & & & & & & \\
\hline \multicolumn{13}{|l|}{ Norit } \\
\hline Norit Japan & 100 & 1982 & 50 & & & 3 & $\mathrm{I}, \mathrm{D}$ & & & chemicals & & \\
\hline
\end{tabular}




\begin{tabular}{|c|c|c|c|c|c|c|c|c|c|c|c|c|}
\hline Name & Own & Establ. & Paid-in & Sales & Income & Empl. & Activ. & Imp. & Exp. & Line of Busines & Partner(s) Stake & Remarks \\
\hline & $\%$ & & Capital & & & & & $\%$ & $\%$ & & & \\
\hline \multicolumn{13}{|l|}{ Hunter Douglas } \\
\hline Hunter Douglas Japan & 77 & 1973 & 93 & 1598 & 107 & 37 & $\mathrm{M}, \mathrm{D}, \mathrm{I}$ & 100 & 0 & aluminium panels & Sankyo Aluminium 23 & \\
\hline Hunter Douglas Window Fashions & 50 & 1989 & 400 & & & 20 & $\mathrm{M}, \mathrm{D}, \mathrm{I}$ & 100 & 0 & blinds & Sekisui Resin 50 & \\
\hline Hunter Douglas Metals Japan & 100 & 1984 & 25 & & & 3 & $\mathrm{D}, \mathrm{I}$ & & & aluminium products & & \\
\hline & & & & & & & & & & & & \\
\hline \multicolumn{13}{|l|}{ Van Leer } \\
\hline Van Leer Japan & 99.5 & 1992 & 40 & & & 5 & $\mathrm{D}, \mathrm{I}$ & 50 & 0 & steel drums & & \\
\hline Tri-Sure Japan & 100 & 1962 & 155 & 194 & & 3 & $\mathrm{D}, \mathrm{I}$ & 70 & 0 & cans and drums & & \\
\hline & & & & & & & & & & & & \\
\hline \multicolumn{13}{|l|}{ Stork } \\
\hline Stork Nippon TP & 100 & 1994 & 10 & & & 11 & $\mathrm{I}, \mathrm{D}$ & & & printing machinery & & \\
\hline \multirow{2}{*}{\multicolumn{13}{|c|}{ Delft Instruments }} \\
\hline & & & & & & & & & & & & \\
\hline Oldelft Japan & 100 & 1968 & 20 & & & 6 & $\mathrm{I}, \mathrm{D}$ & & & Instruments, radar & & \\
\hline & & & & & & & & & & & & \\
\hline \multicolumn{13}{|l|}{ Greenland } \\
\hline \multicolumn{13}{|c|}{ Dutch MNEs in Banking \& Insurance, Services, and International Trade } \\
\hline & & & & & & & & & & & & \\
\hline \multicolumn{13}{|l|}{ Borsumij Wehry } \\
\hline Geo Wehry International & 100 & 1955 & 95 & 3933 & 197 & 47 & $\mathrm{I}, \mathrm{D}$ & 94 & & international trade & & \\
\hline & & & & & & & & & & & & \\
\hline \multicolumn{13}{|l|}{ Van Ommeren } \\
\hline Seino Votanier Logix & 60 & 1985 & 10 & & & & $\mathrm{I}, \mathrm{D}, \mathrm{E}$ & & & international trade & Seino Transport 40 & \\
\hline & & & & & & & & & & & & \\
\hline \multicolumn{13}{|l|}{ Hagemeyer } \\
\hline Hagemeyer Import\&Export & 100 & 1968 & 80 & & & & $\mathrm{I}, \mathrm{D}, \mathrm{E}$ & & & international trade & & \\
\hline & & & & & & & & & & & & \\
\hline \multicolumn{13}{|l|}{ Nedlloyd } \\
\hline Nedlloyd Lines & 100 & 1973 & 100 & 2095 & & 140 & & & & international shipping & & \\
\hline Nedlloyd Lines Nagoya & 50 & 1972 & 30 & & & 30 & & & & transport & & Through Nedlloyd (Hong Kong) \\
\hline & & & & & & & & & & & & \\
\hline \multicolumn{13}{|l|}{ Reed-Elsevier } \\
\hline Excerpta Medica & 100 & 1980 & 60 & & c92 & 41 & $\mathrm{I}, \mathrm{D}$ & & & publishing of medical journals & & \\
\hline
\end{tabular}




\begin{tabular}{|c|c|c|c|c|c|c|c|c|c|c|c|c|}
\hline Name & Own & Establ. & Paid-in & Sales & Income & Empl. & Activ. & Imp. & Exp. & Line of Busines & Partner(s) Stake & Remarks \\
\hline & $\%$ & & Capital & & & & & $\%$ & $\%$ & & & \\
\hline \multicolumn{13}{|l|}{ Baan Company } \\
\hline Baan Japan & 100 & 1995 & 230 & & & 39 & & & & software & & \\
\hline & & & & & & & & & & & & \\
\hline \multicolumn{13}{|l|}{ ABN-Amro } \\
\hline ABN AMRO Bank & 100 & 1950 & & & & 121 & & & & banking & & assets 1187 billion Yen \\
\hline ABN-Amro Securities & 100 & 1987 & 3204 & & 826 & 19 & & & & securities trading & & \\
\hline Mees-Pierson Capital Management & 100 & 1987 & 125 & 124 & & 5 & & & \multicolumn{2}{|r|}{ investment banking } & & \multirow[t]{2}{*}{ International (Switzerland) } \\
\hline & & & & & & & & & & & & \\
\hline \multicolumn{13}{|l|}{ ING } \\
\hline $\begin{array}{lll}\text { Nationale } & \text { Nederlanden } & \text { Life } \\
\text { Insurance }\end{array}$ & 100 & 1984 & 8000 & & & 362 & & & & life insurance & & \\
\hline ING Bank & 100 & 1985 & & & & 71] & & & & banking & & assets 275 billion Yen \\
\hline
\end{tabular}

Notes: Establ. = year of establishment or year of acquisition, paid in capital in million Yen, income is declared taxable income in million Yen, sales is unconsolidated sales in million Yen if not indicated otherwise, Imp. is imports as percentage of total procurement, exp. is export as percentage of sales, $\mathrm{I}=$ import, $\mathrm{M}$ = manufacturing, $\mathrm{D}$ = distribution, $\mathrm{E}=$ export.

a 1990

b 1991

c 1992

d 1993

e 1988

f consolidated basis

Sources: Dodwell (1988, 1992, 1994)), Keizai Chousakai (1994), Toyo Keizai (1995), Dun \& Bradstreet (1996) 
Table 8. Characteristics of Licensing Contracts by Dutch Firms in Japan, 1981-1986

Philips

Number of Contracts: 102

Group Companies: $\quad$ Philips Export (22), Philips Gloeilampen Fabrieken (54), US Philips Corp. (4), Polygram Germany (17)

Total Overseas: $\quad 23$

Main Licensees: $\quad$ Toshiba (6), Pioneer (5), Sanyo Electric (5), Teac (3), Asahi Electric (3), Nippon Columbia (3), Marantz (3)

Intra-Firm: $\quad 6$

Trademarks: $\quad 2$

Products: $\quad$ Micro cassette players (5), other audio (7), CDs and video disks (7), CD cases (24), CD Players (39), semiconductors (9), software (3), colour televisions (3)

Shell

Number of Contracts: 42

Group Companies: Shell International Petroleum (9), Shell International Petroleum UK (3), Shell Oil US (5), Shell Research UK (22), Wavin (1)

Total Overseas: $\quad 32$

Main Licensees: $\quad$ Shell Kosan (4), Showa Oil (7), Sumitomo Chemical (4), Seibu Oil (5), Shukka Shell Epoxy (3), Chiyoda Intra-Firm: $\quad 23$

Trademarks: $\quad 3$

Products: $\quad$ Petrochemicals (10), software (3), chemical processes \& machinery (18), exploration (2)

\section{Akzo-Nobel}

Number of Contracts: 9

Group Companies: $\quad$ Enka (4), Organon (2), AKZO Chemie (2), AKZO Coatings (1)

Intra-Firm: $\quad 1$

Trademarks: $\quad 1$

Products: $\quad$ Paint (1), rubber processing technology (3), chemical machinery (2), plastics (1), general know how (1)

\section{Unilever}

Number of Contracts: 7

Group Companies: Lipton UK (4), Unilever NV (3)

Total Overseas: $\quad 4$

Main Licensees: $\quad$ Lipton Japan (4), Nippon Lever (2)

Intra-Firm: 6

Trademarks: $\quad 4$

Products: $\quad$ Tea (4), soap (1), margarine (1)

DSM

Number of Contracts: 5

Group Companies: $\quad$ Stamiecarbon (4), DSM Resins (1)

Intra-Firm: $\quad 0$

Trademarks: $\quad 0$

Products: $\quad$ Polystyrene (1), chemical machinery (2), polyester (1)

\section{Gist-Brocades}

Number of Contracts: 5

Group Companies: Gist Brocades (5)

Intra-Firm: $\quad 0$

Trademarks:

1

Produts: Pharmaceuticals

Other Firms: $\quad$ KLM (1), SHV (1), Friesland Frico Domo (1), Smit Ovens Nijmegen (3), Marine Structure Consultants (4), Stork (1), Schokbeton (1), Fugro (1), Gispen (1)

Source: calculations based on STA (1982-1987) 